\title{
Rural Development Strategies and Africa's Small Farms
}

\author{
Donald F. Larson, Rie Muraoka, and Keijiro Otsuka
}

\begin{abstract}
Improving the productivity of smallholder farms in sub-Saharan Africa (SSA) offers the best chance of reducing poverty among this generation of rural poor, by building on the few resources farming households already own. It is also the best and shortest path to meet rising food needs. Using examples from farmers' maize and rice fields, comparisons with Asia, and an extensive literature review, we explain why the set of technologies promoted to date have produced localised successes rather than transformational change. We also examine the limitations of alternative policies that are not centred on small farms. We give indicative examples of how resource management technologies can supplement seed-fertiliser technologies to speed an African Green Revolution.
\end{abstract}

\section{Introduction}

The goal of boosting productivity on smallholder farms is a central pillar in the rural development strategies of most African governments. There are many reasons for the broad support given to African smallholders, but two are most often cited. First, the vast natural resources in the hands of smallholder farmers in SSA can be used more productively to feed a growing global population, many of whom will live in Africa. Second, increasing the agricultural incomes through improved technologies offers the shortest path to poverty reduction in rural areas, where poverty has been most persistent. In this essay, we argue that, while it is the second argument that is

This chapter is derived from an original article written by the authors in Global Food Security in 2016. More details can be found in the acknowledgments of the chapter.

D. F. Larson ( $\varangle)$

Global Research Institution, College of William and Mary, Williamsburg, USA

e-mail: don.larson@iides.org

R. Muraoka

Graduate Institute for Policy Studies, Japan Society for the Promotion of Science, Tokyo, Japan

K. Otsuka

Graduate School of Economics, Kobe University, Kobe, Japan

(C) The Author(s) 2020

S. Gomez y Paloma et al. (eds.), The Role of Smallholder Farms in Food

and Nutrition Security, https://doi.org/10.1007/978-3-030-42148-9_4 
especially compelling for policy, finding ways to boost smallholder productivity in Africa offers the best chance of achieving both objectives.

On average, smallholder farmers in Africa would earn higher incomes working in sectors other than agriculture. Also, in countries where land and labour productivity are highest, farms are usually larger than they are in Africa. Furthermore, as economies develop, the proportion of workers in agriculture declines and a larger share of the population lives in cities. So, why should rural development strategies in SSA remain focused on smallholder farms?

The answer has to do with the slow pace of this archetypical economic transformation. For many reasons, the reallocation of labour from agriculture to other sectors is constrained and occurs over generations, even when income gaps are large and sustained. The pace of farm restructuring is slower still, so farms tend to remain small even as agriculture's share of employment declines. Consequently, policies designed to reduce poverty for this generation of rural poor must work largely within the constraints of small farms. In the case of Asia's Green Revolution, new technologies were developed by scientific institutions and quickly adopted by farmers that did just that. What's more, productivity growth rates were sustained while farms remained small. Ultimately, Asia's success influenced African policies, where most strategies to boost productivity have three common elements: a focus on smallholders; an emphasis on staple crops, mostly maize and rice; and a reliance on improved technologies, most often based on fertiliser-responsive high-yielding seeds.

Nevertheless, while the need to drive rural development through improved smallholder productivity is clear, the task is harder in SSA than it was in Asia. Specifically, the agroclimatic and market conditions that predicate the success of technologies are more varied in Africa than in Asia at the start of its Green Revolution. Consequently, a wider portfolio of technologies is needed to launch a transformational African Green Revolution and the task of identifying what works best locally is more difficult. It also means that the seed-fertiliser-focused technologies that work well in Asia, though important, are unlikely to solve all of the key constraints faced by African farmers. This, in turn, holds back sector-wide productivity growth and explains why successes to date have been local rather than sectoral. Part of the solution is to design and deploy a larger set of targeted technologies with local constraints in mind. Drawing on a set of farm studies originally published in Otsuka and Larson (2016), we document how resource management-based technologies can supplement conventional high-yielding seed-fertiliser technologies to improve smallholder productivity in SSA.

\section{Green Revolutions as a Path Out of Rural Poverty}

There are several potential pathways out of poverty for rural households, although none is easy. Family members from poor households often leave rural areas, migrating to cities or to other countries to earn incomes outside of agriculture. Still, studies suggest that potential migrants are often hampered by mismatched skills and 
anchored by illiquid land assets and place-specific social capital, which provide informal forms of insurance otherwise unavailable (Larson et al. 2004). Additionally, the benefits of moving away from agriculture decline with age. Consequently, the window for sectoral migration is brief and constrained. As a result, structural transformation is exceedingly slow and takes generations to achieve (Larson and Mundlak 1997; Gardner 2000; Butzer et al. 2003). In many African countries, it is a process that is far from complete. According to the Food and Agriculture Organization (FAO 2017), and due to the importance of the rural population of SSA (593 million in 2015), a continuous densification of the rural areas is taking place, and the absolute number of people living in rural areas will continue to climb until 2050 with a projected rural population of 909 million (United Nations 2018). In 2010, nearly $60 \%$ of jobs in SSA were in agriculture, and more jobs are expected to be added in this sector by 2020 than in the formal service and industry sectors (Fox et al. 2013). ${ }^{1}$ Consequently, a large portion of the rural poor will remain in agriculture for the foreseeable future and any effective set of policies will have to reach them there.

Rural non-farm income activities offer another path out of poverty and can be key to achieving food security (Otsuka and Yamano 2006; Dethier and Effenberger 2012). However, agriculture is often the engine that drives local non-farm income opportunities, and when it does not, proximity to urban areas is important (Dorosh and Thurlow 2014). Conversely, many remote farmers in SSA have no access to non-farm income at all (Frelat et al. 2016). In addition, there is evidence that more affluent farmers also have better non-farm opportunities, which weakens the links between non-farm income gains and poverty reduction (Bezu et al. 2012; Haggblade et al. 2010; Djurfeldt and Djurfeldt 2013).

In contrast, technological transformations in agriculture can occur in a single generation. During Asia's Green Revolution, new seeds and new farming practices spread quickly, especially among rice and wheat farmers (David and Otsuka 1994; Evenson and Gollin 2003a). As a result, rural incomes grew directly from non-farm productivity gains. Businesses catering to agriculture and farming households also benefited, spurring growth in non-farm employment. Rural families were able to invest in the health and education of their children, helping them to prepare for jobs in other sectors. In short, Asia's Green Revolution transformed rural economies and engendered a type of economic growth that benefited the poor (Rosegrant and Hazell 2000; Hayami and Kikuchi 2000; Hazell 2009).

Furthermore, the dynamics of Asia's success are globally relevant. A wide range of country and cross-country studies suggest that productivity gains in agriculture are a powerful catalyst for poverty reduction and economic growth (de Janvry and Sadoulet 2010; Irz et al. 2001; Diao et al. 2010; Bravo-Ortega and Lederman 2009; Christiaensen et al. 2011; Anríquez and López 2007; Anderson et al. 2010). Conversely, past efforts to promote other sectors at the expense of agriculture slowed growth and lowered incomes instead (Mundlak et al. 1989; Coeymans and Mundlak

\footnotetext{
${ }^{1}$ Fox et al. (2013) estimate that agriculture will account for $37 \%$ of new jobs in SSA between 2010 and 2020; household enterprises will generate $38 \%$ of new jobs, while the formal service and industrial sectors will account for $21 \%$ and $4 \%$, respectively.
} 
1992; Bautista and Valdés 1993). It is worth pointing out that the results are consistent across a wide range of farm structures, including the small farms of Africa and Asia and the larger farms of Latin America.

In most places, policies that distort domestic agricultural prices to favour other sectors have waned; however, this is less true in SSA than in other developing regions (Anderson 2009). Using panel data, Anderson and Brückner (2012) show that a continuation of anti-agricultural policy bias continues to slow overall economic growth in the region. ${ }^{2}$

\section{Scale, Technology Adoption and Global Food Supplies: Past Lessons and Future Prospects}

Despite the many changes brought about by Asia's Green Revolution, sector productivity in Asia is still driven by what happens on small farms, and the same is true in SSA. In East Asia, South Asia and SSA, 95\% of the farms are less than 5 ha in size and these farms occupy most of the farmland in these regions (Lowder et al. 2014). Additionally, historical farm census data suggest that the small scale of farming in Asia and Africa persists, even when economic growth in non-agricultural sectors is high. In fact, if there is a noticeable trend, the trend is towards smaller farms (Table 1).

Still, the small scale of farms in Africa need not stand in the way of technology adoption and productivity gains. Indeed, the breakthroughs that launched Green Revolutions in Asia and Latin America largely centred on seeds, not machines, so the benefits were available to farms of all sizes. Nevertheless, initial adoption rates were highest on Asia's small farms, in part because the technologies worked especially well in places where labour was abundant (Hossain 1977). For example, Evenson and Gollin (2003b, p. 450) reports that by 1998, about $82 \%$ of the area in Asia planted to major crops used improved seeds. In Latin America, where farms are larger, adoption rates were similar for wheat, a significant export crop; however, rates were lower overall, with $62 \%$ of the land planted to modern varieties by 1998 .

Furthermore, there is evidence, mostly from Asia, that an agrarian structure composed mainly of small farms is a better foundation for technology diffusion and overall economic growth (Lipton 2009, Chap. 2). For example, Singh (1985) shows that Indian villages with smaller farms and a more equitable distribution of land adopted Green Revolution (staples) and White Revolution (milk) technologies more quickly than otherwise similar villages. Bardhan and Mookherjee (2006) find similar results in West Bengal during the 1980s and 1990s. At a national level, Jeon and Kim (2000) report production and income gains from Korean land reforms carried out in the 1950s that reduced average farm holding size. Using a cross-country panel, Vollrath (2007) finds that output per hectare improves as land distribution becomes more equitable.

\footnotetext{
${ }^{2}$ Conversely, the authors found no evidence that distorting prices to favour agriculture speeds growth.
} 
Table 1 Average farm size from census data (ha)

\begin{tabular}{|c|c|c|c|c|c|}
\hline & \multicolumn{5}{|c|}{ Decade } \\
\hline & 1960 & 1970 & 1980 & 1990 & 2000 \\
\hline India & 2.70 & 2.30 & 2.00 & 1.60 & 1.30 \\
\hline Indonesia & 1.20 & 1.10 & 1.10 & 0.90 & 0.80 \\
\hline Bangladesh & 1.40 & & 1.30 & & 0.30 \\
\hline China & & & 0.56 & 0.43 & 0.40 \\
\hline Cote d'Ivoire & & 5.00 & & & 3.90 \\
\hline Ethiopia & & 7.30 & 4.20 & 6.20 & \\
\hline Kenya & 11.70 & 4.10 & 2.50 & & \\
\hline Philippines & 3.60 & 3.60 & 2.90 & 2.20 & 2.00 \\
\hline Pakistan & 3.50 & 5.30 & 4.70 & 3.80 & 3.10 \\
\hline Senegal & 3.60 & & & & 4.30 \\
\hline Tanzania & & 1.30 & & 2.80 & 2.40 \\
\hline Thailand & 3.47 & & 3.70 & 3.60 & \\
\hline Uganda & 3.30 & & & 2.20 & \\
\hline Vietnam & & & & 0.50 & 0.70 \\
\hline
\end{tabular}

Source Fan and Chan-Kang (2005), Lowder et al. (2014)

Still, in Africa, the spread of the technologies that launched Asia's Green Revolution stalled. By 1998, only $27 \%$ of farmland in SSA was planted to modern varieties. Adoption rates subsequently improved but remained well below rates on Asia's small farms. By 2005, the adoption rates for new varieties were $45 \%$ for maize, $26 \%$ for rice and 15\% for sorghum (Binswanger-Mkhize and McCalla 2010; Pingali 2012).

Nevertheless, gains outside of Africa were sufficient to drive global food markets. During the first Green Revolution, productivity gains from improvements in crop germplasm boosted global agricultural productivity by $1 \%$ per year for wheat, $0.8 \%$ for rice and 0.7\% for maize (Evenson and Gollin 2003a; Pingali 2012). From 1961 to 2001 , world maize, rice and wheat yields grew annually at $2.1 \%, 1.9 \%$ and $2.3 \%$, respectively, well above the $1.8 \%$ growth in population (FAOSTAT 2015). In Asia, rice yields grew by $2 \%$ annually, and maize and wheat yields grew by more than $3 \%$. Productivity gains outpaced demand growth and real prices for food fell.

Since 2000, the global experience with food prices has changed. Real cereal prices, which declined at an annualised rate of 2.3\% from 1961 to 2000, rose on average by 6.8\% per year between 2000 and 2013; real food prices rose by 5.5\% (World Bank Pink Sheet 2015). Additionally, the period was punctuated with sharp price spikes with harsh consequences for the poor. Although food prices subsequently fell, current projected prices remain above the 1990s levels, but below prices at the start of Asia's Green Revolution (World Bank 2015).

Along with prices, concerns are rising that food security gains will be hard to maintain going forward. The global population is expected to grow to 9 billion before levelling off in 2050, and twice as many people are expected to live in Africa in 2050 
as in 2010 (Godfray et al. 2010b). Income gains, especially in fast-growing Asia, are driving a still-incomplete nutritional transition that features a growing demand for animal protein and feed crops, which compete with food crops for land (Popkin 1998; Delgado et al. 2008). Furthermore, although they represent a poor choice of instruments to address climate change, biofuel mandates and subsidies have become an integral part of agricultural and energy policies, increasing pressure on agricultural resources (de Gorter and Just 2010). ${ }^{3}$

Using projections for food and biofuel demand by Bruinsma (2009) and Fischer (2009), Hall and Richards (2013) calculate that grain yields on current agricultural lands would need to grow by $1.16-1.31 \%$ per year (depending on uncertain policydriven biofuel demand), to keep pace with projected demand by 2050 . The researchers examine known-but-unexploited opportunities to improve yield potentials for rice, maize and wheat, and speculate about promising new technologies, but conclude that current and expected future rates of improvement in genetic potential will be insufficient alone to meet future demand. In general, researchers range from cautious to pessimistic about the ability of new technologies to push the production potential of new seeds to a level sufficient to meet future demand. ${ }^{4}$

Currently, there are signs that productivity growth has stagnated in many areas, falling behind the pace needed to meet future demand, and leaving fewer opportunities for future global gains (Ray et al. 2012, 2013). Poor management of water, fertiliser and pesticides globally, and specifically during Asia's Green Revolution, has degraded land and water resources and has likely played a role in declining yields (Pinstrup-Andersen and Hazell 1985; Pingali and Rosegrant 1994; Godfray et al. 2010a; Stevenson et al. 2013). Moreover, especially in Africa, inadequate fertiliser use has degraded the nutrient content of soils (Cobo et al. 2010; Drechsel et al. 2001). Further ahead are the uncertain consequences of climate change on food production and prices (IPCC 2014). In addition, the anticipated transition to mechanisation in fast-growing countries in Asia, where wages are increasing, may have the unexpected effect of under-cutting future land productivity gains (Otsuka et al. 2016).

Against this background, we discuss two alternative paths to global food security especially relevant for SSA. The first is to expand production by bringing more land and water into agriculture. In general, the potential for bringing more natural resources into agriculture in a sustainable way is limited, especially once agricultural lands lost to urbanisation and competing resource demands are taken into account. Nevertheless, many researchers conclude that there is scope, especially in SSA. An alternative approach is to improve the productivity of existing farms. ${ }^{5}$ There are a number of places worldwide where there is significant potential to "close yield

\footnotetext{
${ }^{3}$ Fischer (2009) estimates that biofuels will add an additional 9-19\% to global cereal demand by 2050.

${ }^{4}$ See references in Hall and Richards (2013). See Khush (2013) for an assessment of opportunities for higher yielding rice varieties and Hawkesford et al. (2013) for wheat. Thornton (2010) discusses livestock technologies and the potential for feeding efficiencies.

${ }^{5}$ Godfray et al. (2010a) suggest three additional paths: reducing waste, changing diets and expanding aquaculture.
} 
gaps' - that is, to reduce the gap between productivity obtained and determined potential productivity, by using the best available genetic materials and technologies. However, some of the largest yield gaps are to be found in SSA, where most agricultural resources are managed by smallholder farmers.

\section{Smallholder Resources in SSA as a Solution to Future Food Needs}

Studies show that staple crop yields could be improved by using better seeds and better nutrients, and by improving water management (Neumann et al. 2010; McDermott et al. 2010; Mueller et al. 2012). This is especially true for SSA, where yield gaps and poverty are linked (Dzanku et al. 2015). For example, in their global study, Mueller et al. (2012) note that some of the largest yield gaps - the difference between potential and actual yields_-are for African staple cereals.

Alternatively, it is also possible to expand food production in Africa by planting more land to crops in places where agricultural land remains relatively abundant. Deininger et al. (2011) estimate that more than 200 million hectares in SSA could be converted to rainfed agriculture, roughly $45 \%$ of the total area in the world suitable for expansion. Much of the land is isolated; however, they calculate that about 95 million hectares could be accessed without a major investment in infrastructure. In the case of rice, Balasubramanian et al. (2007) estimate that, once double cropping is taken into account, upwards of an additional 236 million hectares of agroclimatically suitable wetlands are available in Africa. Additionally, they argue that the expansion of rice production need not compete with other food crops, since much of the low-lying wetlands suitable for rice are inhospitable for other crops. ${ }^{6}$

Still, converting new lands to agriculture seems like an unlikely path to expanding crop production. On average, the share of agricultural land cropped in Africa stands at $22 \%$, leaving large tracts of meadow and pastureland available to convert to crops with fewer upfront costs to farmers. ${ }^{7}$ In addition, there are also important advantages to spending public resources on improving the productivity of existing farms, rather than investing in infrastructure or incentives to carve out new farms. For example, Deininger and Byerlee (2012) estimate that quadrupling maize production through area expansion alone would require 90 million new hectares. Alternatively, decreasing average maize yield gaps in SSA from 80 to $20 \%$ would bring about an equivalent increase on existing cropped land, leaving land and water sources to sustain natural

\footnotetext{
${ }^{6}$ Authors providing estimates of available land are keen to note that the exercise is speculative. One key obstacle is reaching an informed assessment of soil quality (See de Paul Obade and Lal 2013).

${ }^{7}$ In contrast, $87 \%$ of agricultural land in Southeast Asia is cropped.
} 
ecosystems and the services they provide, including carbon sequestration (Satterthwaite et al. 2010; Godfray et al. 2010a, b). ${ }^{8}$ Furthermore, closing the yield gap by improving soil nutrient management could halt and possibly reverse the problem of declining soil fertility in Africa (Deugd et al. 1998; Place et al. 2003; Zerfu and Larson 2010).

Even so, while there is widespread agreement that boosting productivity on current lands is the preferred approach to expanding food production, there is less agreement on how to close yield gaps, and even disagreement on the relevance of calculated yield gaps. To begin with, potential yields are usually based on selected genetic material combined with inputs, especially chemical fertiliser that must be purchased (Lobell et al. 2009). Tautologically, fully closing the gap means inducing farmers to take up the technologies implicit in calculating the gap. As discussed below, seedfertiliser technologies work well for some crops in some parts of SSA. In other places, the technologies are simply not adopted. This has led some to question the relevance of conventional yield gap measures and propose alternative measures. For example, Tittonell and Giller (2013) suggest calculating productivity potential based on ecologically intensive farming methods. These methods, which depend on ecological processes to minimise perpetual purchased inputs, can be indicative where fertiliser and other inputs are expensive relative to output value. Tittonell and Giller (2013) note that common elements of ecological intensification, such as integrated cropping and livestock practices, are already present in many African farming systems; however, they also warn that ecologically intensive systems will not suit the needs of all farmers. Marenya and Barret (2007) make the same point, arguing that poor smallholders in western Kenya are unable to afford integrated soil fertility management techniques.

A similar argument applies to water management technologies. Discussions about yield potentials often distinguish between plentiful and scarce water conditions (e.g. Hall and Richards 2013). While it is easy to think about large state-financed irrigation systems that dramatically change water scarcity, there are less capital-intensive water management technologies, such as bunding and levelling, which significantly add to the marginal value of complementary purchased inputs and to productivity overall. As Lipton (2012) points out, this was also the case at the start of Asia's Green Revolution, when farmers often employed simple labour-intensive irrigation systems, including systems that relied on hand-operated pumps and animal-lifted water.

More generally, calculated yield gaps, regardless of methodology, ultimately depend on a technology choice that may or may not be relevant for place-specific livelihood strategies. For this reason, yield gaps are useful as an indicator of prevailing technology choices, relative to a practical standard, but provide less insight into how yield gaps come about or how they might be closed. In Sect. 7, we return to the topic and discuss practical aspects of technology choices and the role of policy.

\footnotetext{
${ }^{8}$ Converting pastureland, though less impactful than carving out new farms, can also have negative environmental consequences, especially when soils or climate make the areas marginal for annual crops. The effects of conversion are place-specific and highly variable. See, for example, Alem and Pavlis (2014), Searchinger et al. (2015).
} 


\section{Alternative Rural Development Strategies Based on Larger Farms}

The potential for agriculture to grow through expansion, together with dissatisfaction over the uneven pace of yield gains among African smallholders, has given rise to an active debate about smallholder-focused rural development strategies (Lipton 2006; Hazell et al. 2010; Wiggins et al. 2010; Collier and Dercon 2014). Critics argue that small farms forego economies of scale in terms of skills, technology, finance and capital, and face diseconomies in terms of trading, marketing and storage, disadvantages that will become more pronounced as a larger share of the population moves to cities and as rural labour wages converge towards the higher levels found in other sectors (Maxwell and Slater 2003; Collier and Dercon 2014). Consequently, they argue, policies should rely on larger commercial farms to generate productivity gains, while relying on accelerating growth in other sectors to reduce poverty among the rural poor.

The notion that agricultural policies should not neglect larger farms is not controversial. In particular, government efforts to protect security of tenure and property rights and to promote land markets (for rentals and sales) are expected to both benefit smallholders currently and set the stage for an emerging class of medium-sized, commercial farms (Jayne et al. 2014). However, it seems unlikely that shifting budgetary resources away from smallholder farms to support large-farm programmes will help this generation of rural poor or boost global food supplies any time soon.

Farm census, data show there are relatively few large farms in SSA, and there is little to suggest that market forces are driving widespread consolidation (Masters et al. 2013). In addition, there are good conceptual reasons to suggest a smallholder structure is well suited for most places in SSA, where land, labour, risk and credit markets are imperfect (Binswanger and Rosenzweig 1981; Feder 1985).

There are several reasons why Africa's farm structure is based on small farms, but most development economists see two aspects of labour markets as fundamental. ${ }^{9}$ The first has to do with supervision and incentives. To start, the incentives to farm diligently and to manage soil and other natural resources are greater for family members than for hired labour. In addition, reliable hired labour can be costly to find and to supervise, which lowers the value of hired labour relative to the value of family labour (Yotopoulos and Lau 1973; Kumar 1979). For this reason, most farms in the world are family-operated-about $75 \%$ of all farms according to Lowder et al. (2016). In itself, family ownership is not tied to scale; however, when the transition of labour markets is in its early stages, labour costs are lower in agriculture than in other sectors, which tilts profitable technology choices away from mechanisation and towards labour-intensive technologies. Poor access to credit reinforces this tilt, since farmers can improve their farms through 'sweat equity', for example, by levelling fields or building fences, with little or no credit. Taken together, this means that the best-suited technologies are associated with small farms managed and worked

\footnotetext{
${ }^{9}$ See Lipton (2009, Chap. 2) for an integrated treatment and an excellent review of the empirical literature.
} 
primarily by household members. Therefore, the most productive farms will be small in most places in SSA. Poorly functioning land markets also work to help keep farms small, because they keep the risks and costs of renting or purchasing land unnecessarily high (Lipton 2009; Deninger et al. 2014).

In many places in Africa, input and output markets are plagued by high transport and transaction costs, which tend to raise farm-gate input prices and lower output prices. In general, this works against high-yielding technologies that rely on purchased inputs, especially fertiliser. It also encourages the adoption of livelihood strategies built around producing some or all of the household's food, since doing so avoids the high transport and transaction costs embedded in purchased food, and discourages the adoption of alternative strategies based on commercial sales, which rely more on markets. This strategic choice comes at a cost, since families may forego planting alternative income-producing crops and forego alternative non-farm activities that are more profitable on average; however, the strategy can prove crucial when food prices surge. ${ }^{10}$ Nevertheless, once the decision to produce food for home consumption is taken, price and output risk can lead families on smaller farms to use more household labour and obtain higher yields than neighbours on larger farms (Srinivasan 1972; Barrett 1996).

Regardless of its conceptual underpinnings, there is considerable evidence that productivity, especially land productivity, is higher on small farms than on larger ones in developing countries. Moreover, evidence of an inverse relationship between productivity and farm size is found across a large number of farming systems of varying average scale and under a variety of agroclimatic conditions. [See the literature reviewed in Binswanger et al. (1993), Lipton (2009), and Eastwood et al. (2010)]. In SSA, inverse relationships have been found in Ethiopia (Cornia 1985; Nega et al. 2003), Kenya (Larson et al. 2014), Madagascar (Barrett 1996), Nigeria (Cornia 1985), Malawi (Larson et al. 2014), Rwanda (Byiringiro and Reardon 1996; Ali and Deininger 2015), South Africa (van Zyl et al. 1995), Tanzania (Cornia 1985; Larson et al. 2014), Uganda (Cornia 1985; Nkonya et al. 2004; Matsumoto and Yamano 2013; Larson et al. 2014) and Zambia (Kimhi 2006). ${ }^{11}$

Still, some researchers are sceptical of these results and speculate that they are statistical artefacts. One line of reasoning is that smallholder lands are more productive because farmers are less likely to sell or rent out their highest quality land. As a consequence, productivity differences may be falsely attributed to scale, since land quality usually goes unmeasured (Assunção and Braido 2007; Benjamin 1995; Bhalla and Roy 1988; Lamb 2003). Potentially, systematic measurement errors in self-reported area and yields may also bias empirical results (Lamb 2003). The empirical evidence addressing either criticism is thin, but a study by Barrett et al. (2010)

\footnotetext{
${ }^{10}$ See Yamauchi and Larson (2016) and references therein for a discussion about the effects of food price crises on child health.

${ }^{11}$ An inverse relationship is often found outside of SSA, where the average scale of farms is more varied. For example, inverse relationships have been found in Barbados (Cornia 1985), Brazil (Kutcher and Scandizzo 1981; Berry 1984), the Indian Punjab (Sen 1966), Malaysia (Berry 1984), Mexico (Cornia 1985), the Philippines (Hayami et al. 1990), the Republic of Korea (Cornia 1985) and West Bengal (Carter 1984).
} 
that includes soil measurements finds no evidence of systematic bias for measured yields. Matsumoto and Yamano (2013) found inverse relationships between maize yields and plot size from estimated models that include and exclude soil carbon levels. Additionally, a recent study that incorporates self-reported and GPS-measured plot areas in Uganda concludes that measurement errors work against, rather than in favour of, the inverse yield hypothesis (Carletto et al. 2013).

Some critics discount the inverse productivity findings, arguing that the empirical samples behind the studies are composed mainly of small farms (Collier and Dercon 2014). This latter criticism is unfounded, especially when studies outside of Africa are considered. More importantly, the criticism also misses the larger point that, among the applied technologies used by a large representative class of farmers, there is no evidence that significant production economies are given up by staying small. In fact, the empirical evidence suggests the opposite: that the small-scale structure of SSA agriculture is an efficient way to use land and labour resources, given prevailing market conditions and constraints. For policy, this means that the full benefit of scale-neutral technology innovations, such as the development of improved seeds, can be achieved without augmenting the limited set of assets, mostly land and family labour, that smallholder farmers already possess. This is not to say that African farms should stay small, but it does offer a path for reducing poverty and building global food supplies without waiting for labour markets, capital markets and farm structures to change.

As an alternative to smallholder-centred policies, some researchers suggest promoting larger commercial farms on new land, by taking advantage of investor interest in acquiring large tracts of agricultural lands (Collier and Dercon 2014). The strategy is risky, and even proponents urge taking a cautious and experimental approach (Collier and Venables 2012). This is because the history of government-managed land transfers is poor, especially in Africa (Eicher and Baker 1982; Andrae and Beckman 1985; Zoomers 2010; Borras et al. 2011; Deininger and Byerlee 2012). Moreover, Arezki et al. (2015) report worrisome evidence that current interest in African land deals is highest where land governance and tenure security are weak. ${ }^{12}$

Given the need for caution, programmes to develop new farms are unlikely to have a significant impact on food supplies any time soon and seem a less strategic use of resources when compared to programmes designed to achieve small increases in the yields of current farmers. Furthermore, as discussed, improving smallholder yields would likely generate greater economic growth and larger reductions in poverty than large-farm strategies, even when the effects on global food supplies are equivalent.

\footnotetext{
${ }^{12}$ Byerlee et al. (2017) document an alternative approach where developers invest in improving frontier lands with the intention of selling subdivided parcels to individual family-run farms. The approach resolves upfront investment hurdles while ultimately resulting in the creation of new family-scaled farms.
} 


\section{Revolution or Evolution?}

Many of the comparisons between Africa now and tropical Asia prior to its Green Revolution are apt. At the start of Asia's Green Revolution, agriculture was structured around small farms. Yields of the two main staple crops, rice and wheat, had been stagnant while populations grew. Consequently, food insecurity and fear of famine were widespread (Meadows et al. 1972; Drèze and Sen 1989; Otsuka and Place 2015). However, in Asia, new technologies - once proven-were quickly taken up with exceptional results. In contrast, progress in Africa has been characterised by a mosaic of local successes that are hard to detect in national or regional numbers (Reij and Smaling 2008; Otsuka and Larson 2013). ${ }^{13}$ In turn, this has fed disappointment among donors with policies meant to improve smallholder productivity and has promoted a view that the smallholder policy narrative has been oversold (Dercon 2013).

However, there are also key differences that make an African Green Revolution harder to achieve. First is the diversity of agroclimatic-based food systems and the related diversity in the staple crops that are the foundation of African diets. This point is illustrated in the top panel of Fig. 1, which shows the share of calories originating in the two major grains for SSA (rice and maize) in 2010 and also the share of calories originating in wheat and rice for South and Southeast Asia, at the start of Asia's Green Revolution. ${ }^{14}$ The country values presented in the figures are ranked from lowest to highest. In Asia, food systems had emerged based on large east-westoriented agroclimatic zones, well suited for wheat and rice. Additionally, weather variations were mitigated by investments in irrigation. ${ }^{15}$ By 1965 , more than $46 \%$ of the calories available in every country of South and Southeast Asia came from rice or wheat; in populous Thailand, Vietnam and Bangladesh, the shares exceeded $65 \%$. Consequently, technological innovations in wheat and rice, once adopted, had the potential for large system-wide impacts on productivity, incomes and nutrition.

In contrast, the food systems in Africa, supported by largely north-south oriented agroclimatic zones, are more varied. In 2010, only food systems in Malawi, Zambia, Lesotho and Madagascar depended mostly on maize and rice. Consequently, the successful adoption of a single high-yielding crop technology-for example, highyielding lowland rice — can be important regionally without adding up to system-wide impacts. In other words, the number of crop innovations must be greater in Africa to generate a continental Green Revolution.

Another significant difference has to do with land availability. The lower panel of Fig. 1 shows the portion of agricultural land planted to annual or permanent crops,

\footnotetext{
${ }^{13}$ Lipton (2012) makes a similar point citing more accurately measured weight-and-height data.

${ }^{14}$ Cassava is another important crop and one that, historically, has been more important than rice in SSA. Statistics on cassava consumption are prone to error, since a large share of domestic production is not marketed. However, FAOSTAT (2015) data for 2010 suggest that rice generates about 244 calories per capita per day for the region, compared to 191 calories for cassava.

${ }^{15}$ In 1965, about $12 \%$ of cropland in Southeast Asia and 20\% in South Asia was equipped for irrigation. In contrast, only 3\% of cropland in SSA was equipped for irrigation in 2013.
} 

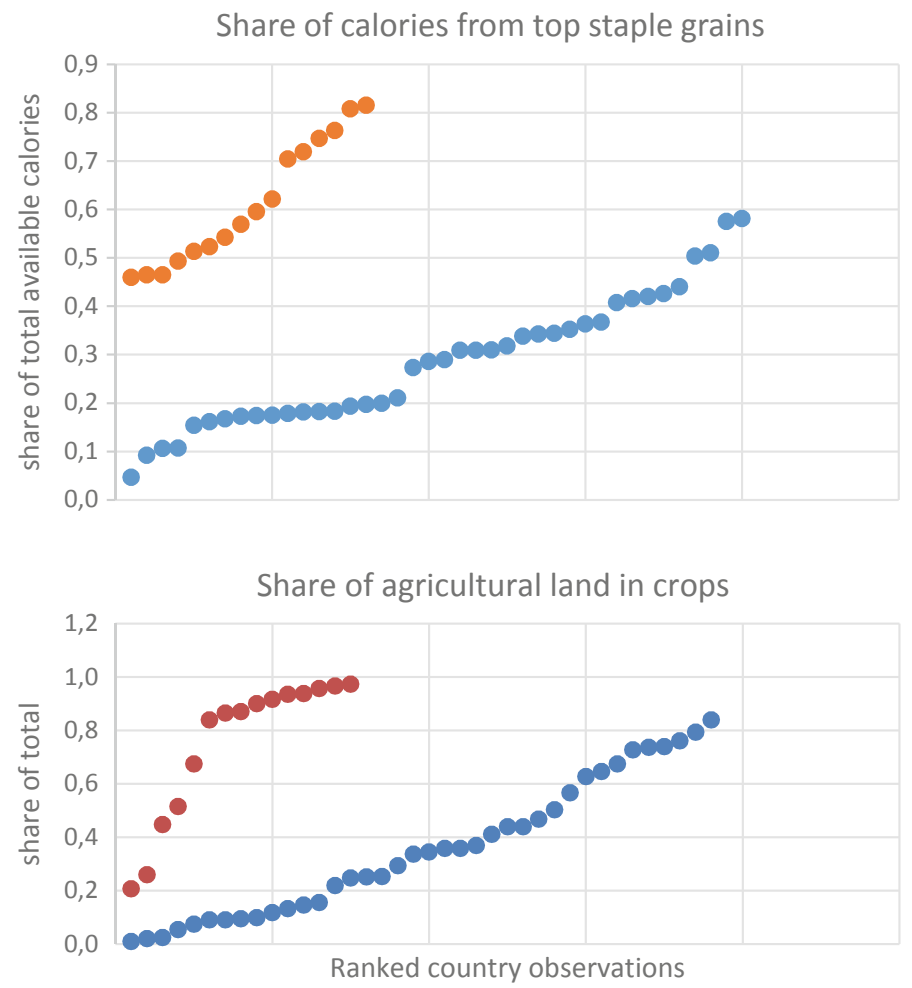

- Sub-Saharan Africa 2010

- South and Southeast Asia, 1965

Fig. 1 Starting points for South and Southeast Asia, and Sub-Saharan Africa. Source FAOSTAT (2015); authors' calculations. Notes The figures plot ranked country average values from lowest to highest. For SSA, reported calories originate in rice, maize. For South and Southeast Asia, the reported calories originate in rice, wheat

with the remaining portion devoted to meadows and pastureland. In the places where Asia's Green Revolution found early success, such as Pakistan, India and Thailand, more than $85 \%$ of available agricultural land was already cropped, leaving little room to expand by converting pastureland. In Asia, the technologies that proved successful were fertiliser-responsive high-yielding varieties of rice and wheat, which greatly improved land productivity. Because household landholdings were also small, the seed-fertiliser technologies solved a constraint faced by many farming households, as well as a primary constraint for the sector as a whole (Johnston and Cownie 1969).

Land availability is more varied in SSA. In places such as Mozambique and Liberia, large tracts of pastureland are available for conversion. But more than 74\% of the land is already cropped in Burundi, Rwanda and Cameroon. Consequently, technologies that boost land productivity are more relevant in some places than others. In addition, differences in transportation and transaction costs are often greater 
in more sparsely populated land-abundant countries. This also affects technology choices, since remote households farming where input prices are higher and output prices lower will find fertiliser-intensive technologies less attractive (Larson and Gurara 2013). This point is brought home by considerable empirical evidence that farmers' preferences for varieties reflect more than potential yields (Adesina and Baidu-Forson 1995; de Groote et al. 2002; Lunduka et al. 2012). ${ }^{16}$

The diversity of economic and agroclimatic conditions, and its implications for the suitability of any single technology, also complicates the design and implementation of programmes meant to disseminate developed technologies. In Asia, national campaigns to improve smallholder productivity could be built around one or two crops, with standard knowledge bases. Moreover, lessons gained from the same crops in one country could be adopted in the next. In Africa, regional campaigns with multiple technologies and varying knowledge bases are needed to achieve the same aggregate impact. In addition, research and extension successes in a handful of populous countries in Asia led to significant global impacts, while success in SSA depends on making headway across 49 independent national research and extension systems.

In addition, Africa's Green Revolution got off to a slow start. The foundation for Asia's early success was already in place by 1965, based on a large stock of improved germplasm from temperate zones, wheat varieties from North America, Europe and Japan, and rice cultivars derived from Taiwanese and Japanese semidwarfs (Evenson and Gollin 2003c). In contrast, international breeding programmes for sorghum, millet, barley, lentils, potatoes and cassava-crops that are important in Africa-did not begin until the 1970s, and rice programmes for Africa did not start until the 1980s. Additionally, African governments have been less willing to invest in agriculture in general, and in agricultural research specifically. Based on available data, Pardey et al. (2006) note that 44 countries in SSA spent a combined USD 3.8 billion on agricultural research in 2000 . By way of contrast, India invested almost USD 21 billion and China invested more than USD 48 billion during the same year. ${ }^{17}$

Because of the great diversity of circumstances that condition smallholder technology choices, the smaller initial portfolio of relevant technologies, and a history of meagre support for agricultural research, Africa's Green Revolution has been slower to evolve than Asia's. It has also meant that successes to date have been dispersed and the cumulative effects of success harder to discern. Even so, there are signs that the gap in cereal yields is beginning to close in some places. ${ }^{18}$ Figure 2 shows annualised

\footnotetext{
${ }^{16}$ For example, Diagne et al. (2013) posit that some farmers were attracted to Nerica rice because of its shorter growing season despite similar observed yields. In Burkina Faso, Dao et al. (2015) find seed colour and drought resistance are important factors for maize farmers. The researchers also find regional differences in preferred traits.

${ }^{17}$ In 2003, African governments entered into a pledge, known as the Maputo Declaration, to allocate $10 \%$ of government expenditures to agriculture in order to address past neglect. Benin and $\mathrm{Yu}$ (2013) report that progress towards meeting pledged goals has been mixed.

${ }^{18}$ National governments and the international community have also under-invested in gathering agricultural statistics, which makes international comparisons indicative at best. Furthermore, better measured yields from households are not representative of national outcomes, since they are drawn from a sample of households rather than farms.
} 


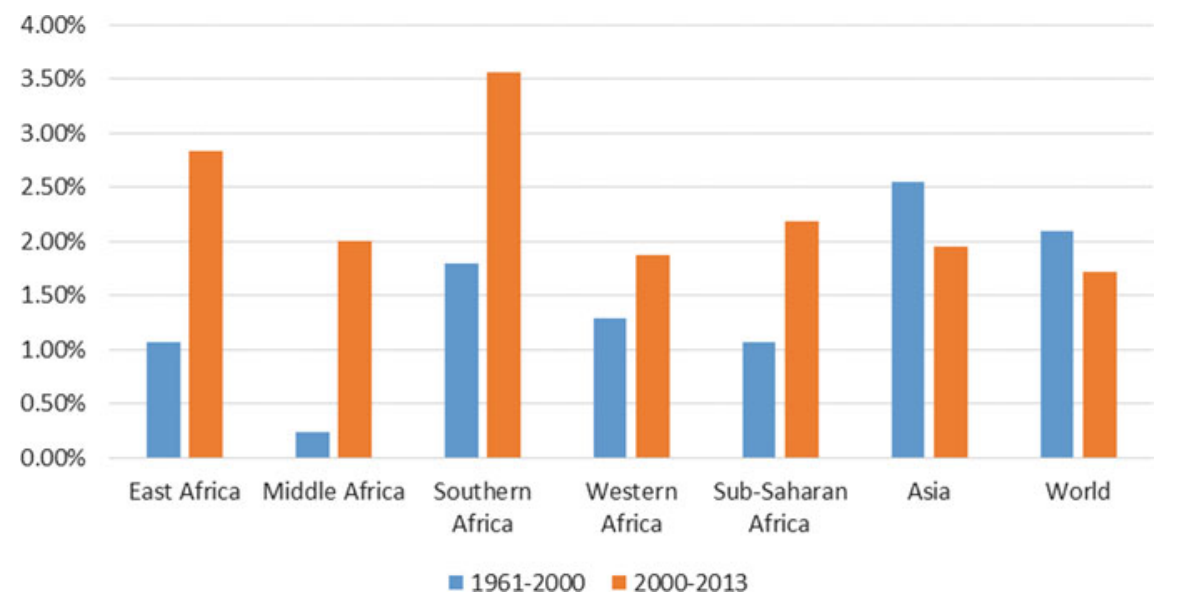

Fig. 2 Annualised rates of yield growth for cereals, Africa, Asia, and World. Source FAOSTAT (2015); authors' calculations. Note East Africa includes: Burundi, Comoros, Djibouti, Kenya, Madagascar, Malawi, Mauritius, Mozambique, Eritrea, Zimbabwe, Réunion, Rwanda, Somalia, United Republic of Tanzania, Uganda, Ethiopia and Zambia. Middle Africa includes: Angola, Cameroon, Central African Republic, Chad, Congo, Gabon, Sao Tome, Principe, and the Democratic Republic of the Congo. Southern Africa includes: Botswana, Lesotho, Namibia, South Africa and Swaziland. West Africa includes: Cabo Verde, Benin, Gambia, Ghana, Guinea, Côte d'Ivoire, Liberia, Mali, Mauritania, Niger, Nigeria, Guinea-Bissau, Senegal, Sierra Leone, Togo and Burkina Faso

growth rates in yields for two periods: the twentieth century Green Revolution years 1961-2000 and the more recent period 2000-2013. During the first period, growth in Asian cereal yield outpaced that in SSA by a wide margin. Since then, Asian yield growth rates have slowed somewhat, as have average world rates. However, growth rates in SSA have accelerated. The figure shows considerable regional differences for both periods, with the largest yield gains occurring in Southern Africa. Keeping in mind that yield improvements in Asia have been sustained for six decades, it is clear that the yield gap between Asia and SSA remains large. However, the recent differential growth rates in crop yields do suggest that the gap between Asia and parts of Africa have begun to close.

\section{Lessons from Farmers' Fields}

In this section, we focus on elements of maize and rice productivity in SSA that illustrate why the task of developing and disseminating appropriate smallholder technologies is complex in SSA, and provide some examples of technologies that have succeeded. The section draws on seven country studies focused on irrigated and 
non-irrigated rice technologies, rainfed maize technologies, irrigation systems management, training and credit programmes. The detailed studies are reported in Otsuka and Larson (2016).

\subsection{Maize}

Recent empirical studies suggest that the adoption of technologies built on highyielding fertiliser-responsive modern varieties (MVs) significantly increases crop revenue and household income (Bezu et al. 2014; Khonje et al. 2015; Mathenge et al. 2014), reduces poverty (Khonje et al. 2015; Mathenge et al. 2014; Zeng et al. 2015) and improves food security (Bezu et al. 2014; Khonje et al. 2015; Smale et al. 2015). Nevertheless, regional adoption rates for MV maize vary significantly, and in many places, most farmers use traditional maize technologies. For example, Smale et al. (2013) report the following MV adoption rates for 2006-2007: 33\% of maize area in Eastern Africa; 52\% in Southern Africa, excluding South Africa; and 60\% in West and Central Africa. Drawing on data from 2001 to 2006, Kostandini et al. (2013) also report considerable variations in MV adoption rates among countries, ranging from 5\% in Angola to over 70\% in Kenya and Zambia. ${ }^{19}$

As in Asia, the full benefits of the maize technologies developed for Africa are only achieved with high levels of soil nutrients, which in practice calls for the use of chemical fertilisers (Morris et al. 2007). There is ample evidence that the MV technologies, once adopted and used in combination with fertiliser, perform as expected. For example, estimated marginal response rates of maize to fertiliser range from $12 \mathrm{~kg}$ maize per $\mathrm{kg}$ of nitrogen application in Zambia (Xu et al. 2009) to $25 \mathrm{~kg}$ in Kenya (Matsumoto and Yamano 2013). In addition, studies suggest that adopting seed-fertiliser maize technologies is profitable in: Western, Eastern and Southern Africa (Morris et al. 2007); Kenya (Sheahan et al. 2013; Matsumoto and Yamano (2013); Uganda (Matsumoto and Yamano 2013); and Zambia (Xu et al. 2009). Yet the share of farmers that apply fertiliser to maize plots varies widely. For example, Sheahan et al. (2013) report use rates of 76\% in Kenya in 2010; Matsumoto and Yamano (2013) report use rates of 74\% in central and western Kenya in 2004 and 2007. In neighbouring Uganda, Larson et al. (2016) found that $6 \%$ of maize farmers used fertiliser in 2009-2010; Matsumoto and Yamano (2013) report a 3\% share.

As discussed, boosting the adoption of MV technologies is often the key proximate objective of rural development strategies, so the question of why adoption rates are often low among African maize farmers has received considerable attention. Recently, discussions have focused on rates of fertiliser use, which are low when compared to recommended levels and in comparison to typical practices on Asia's

\footnotetext{
${ }^{19}$ Regional and national MV adoption rates were extracted from DTMA seed sector surveys for Eastern African and Southern Africa (Langyintuo et al. 2010) and from Alene et al. (2009)'s own survey. Both data sets are based on interview surveys from maize seed companies, national research organisations and community-based organisations.
} 
small farms. In the case of maize, there is often evidence that MV technologies are welfare improving, so much of the recent debate has focused not on the technology promoted, but on information gaps, market failings and 'non-fully rational behaviour' (Larson et al. 2016; Duflo et al. 2008). Generally, policy advocates agree on the need for governments to invest more in infrastructure and other public goods, which tend to lower barriers to technology and markets, but there is less agreement about whether additional interventions are needed.

\subsubsection{Appropriate Technology but Inadequate Promotional Programmes?}

One area of debate is whether the market reforms eliminating grain and fertiliser parastatals, which accelerated in the 1990s, stunted the adoption of high-yielding varieties (Akiyama et al. 2003; Crawford et al. 2003; Jayne et al. 2003; Morris et al. 2007). A related debate concerns the importance of supported output prices and subsidies on fertiliser, irrigation, power and credit during the early stages of Asia's Green Revolution (Timmer 1997; Johnson et al. 2003). Some conclude that markets have failed in Africa and call for greater state intervention (Moseley et al. 2010; Poulton et al. 2006; Winter-Nelson and Temu 2005). Still, in the case of maize, there have been several aggressive state-sponsored campaigns reminiscent of the early programmes in Asia, and, more recently, national programmes built around subsidised inputs (Jayne and Rashid 2013).

Perhaps the effort most comparable to the Asian programmes was the Global 2000 Campaign, promoted by Norman Borlaug (who had been awarded a Nobel Prize for his work on Asia's Green Revolution), former US President Jimmy Carter, and Japanese billionaire philanthropist Ryoichi Sasakawa. The regional programme, begun in Ghana in 1986, was designed to promote the hands-on transfer of MV maize technology by offering a selected package of seeds, fertiliser and extension services to a small cadre of farmers (Brinkley 1996). In Ghana, maize yields tripled on early demonstration plots, and by 1989 , nearly 80,000 farmers had adopted the recommended MV technology. Nevertheless, Tripp (1993) argues that many of the technologies promoted were not consistently the best technologies in all regions of Ghana and were often marginally profitable under ideal conditions. When poor weather inevitably arrived, many farmers were unable to repay loans, and soon many of the farmers who had adopted the technology abandoned it. A 1990 survey found that only $29 \%$ of the farmers who first used fertiliser under the programme continued to use it (Tripp 1993, p. 2012).

Similar programmes were launched for maize in Ethiopia, Ghana, Kenya, Malawi, Mozambique, Sudan, Zambia and Zimbabwe (Brinkley 1996; Howard et al. 2003; Smale and Jayne 2010; Smale 1994). Some programmes showed early success before reaching an adoption plateau; however, adoption gains were often reversed and new technologies abandoned. Frequently, adoption depended heavily on controlled prices or subsidies that proved too expensive to maintain. Similarly, researchers are finding 
that several recently launched campaigns to promote MV technologies with subsides are proving expensive with at best marginal benefits (Ricker-Gilbert et al. 2013; Jayne and Rashid 2013). ${ }^{20}$

\subsubsection{Heterogeneous Conditions, Livelihood Strategies and Technologies}

An alternative explanation is that the circumstances that affect the profitability of a given technology are heterogeneous, so it is unlikely that all farmers will decide to use the same technology. In this sense, the choice of technology is endogenous (Mundlak 1988; Mundlak et al. 2012). Differences in natural endowments, for example, soil fertility or water availability, affect fertiliser response rates and yields, and therefore the profitability of a given technology (Larson and Leon 2006; Marenya and Barrett 2009; Jayne and Rashid 2013). Variable weather may add to the risk of a technology, even if the technology is profitable on average (Larson et al. 2016); however, price and weather risks can encourage the use of inputs, especially family labour, which affect the relative productivity of technology choices (Srinivasan 1972; Barrett 1996). Spatial differences in transport and transaction costs also affect relative profitability (Xu et al. 2009). In the specific case of maize, Suri (2011) concludes that in Kenya, differences in the costs and benefits of using maize hybrids explain the differences in choices made by adopters and non-adopters of MV technologies. In short, there are differences in the market prices and relevant shadow prices faced by farmers, which generate variations in livelihood strategies pursued and technologies employed. ${ }^{21}$

Practical differences in technology preferences are illustrated by Table 2, which shows that input intensities such as chemical fertiliser and manure application per hectare, the share of intercropped fields, and the percentage of adoption of hybrid seeds are all substantially higher in Kenya than in Uganda, which resulted in higher maize yields and higher crop income in Kenya than in Uganda. Nevertheless, in the case of Uganda, the use of low input, low yield technologies are consistent with weather-related yield risks (Larson et al. 2016).

\subsubsection{The Integrated Maize Farming System}

While research and extension programmes often focus on high-yielding seedfertiliser technologies, another approach is to adopt integrated soil fertility management systems, which use both organic and inorganic fertilisers. For example, in India, Kajisa and Palanichamy (2013) found that application of organic fertiliser directly

\footnotetext{
${ }^{20}$ Jayne and Rashid (2013) report that the 10 African countries covered in their review spent about $29 \%$ of their agricultural budgets on input subsidies in 2011.

${ }^{21}$ Moreover, conditions are not static but evolve, especially as urbanisation generates new demand and new markets for food. See, for example, the discussion about the role of markets in Haggblade and Hazell (2010).
} 
Table 2 Maize technology adoption in Kenya and Uganda

\begin{tabular}{l|l|l|l}
\hline & \multicolumn{2}{|l|}{ Kenya } & Uganda \\
\cline { 2 - 4 } & 2004 & 2012 & $2009 / 2010$ \\
\hline Maize yield (tons/ha) & 1.8 & 2.1 & 1.2 \\
\hline Crop income (KSh/ha) & 37,869 & 46,786 & - \\
\hline $\begin{array}{l}\text { Chemical fertiliser use } \\
\text { (kg/ha) }\end{array}$ & 49 & 47 & 0.3 \\
\hline Manure use (kg/ha) & 971 & 1578 & 22 \\
\hline $\begin{array}{l}\text { Share of intercropped fields } \\
(\%)\end{array}$ & 76 & 72 & 45 \\
\hline $\begin{array}{l}\text { Adoption of hybrid maize } \\
(\%)\end{array}$ & 50 & 78 & 30 \\
\hline
\end{tabular}

Note Adoption rates are based on share of farmers surveyed. Source Larson et al. (2016), Muraoka et al. (2016). Crop income is defined as crop production minus all paid costs associated with crop production. The Uganda data is nationally representative of households. Data for Kenya is based on household surveys drawn from the west and central highlands

increased productivity of upland cereals and also raised the efficacy of chemical fertilisers in low fertility soils. Evidence from Malawi and Kenya shows that intercropping or rotating maize with nitrogen-fixing legumes is another possible way to restore soil nutrients (Ojiem et al. 2014; Snapp et al. 2010). In Central and West Africa, farmers fallow land to restore soil fertility and use biological indicators to judge fertility restoration levels (Norgrove and Hauser 2016).

A more complex integrated maize technology, which seems to work well in populous areas that are also free from sleeping sickness, is examined by Muraoka et al. (2016) and Otsuka and Yamano (2005). In the highlands of Kenya, farmers who adopt this system grow forage crops such as Napier grass and feed it to genetically improved stall-fed cows, from which they produce manure. They apply the manure along with chemical fertilisers to fields planted with hybrid maize varieties, often intercropped with nitrogen-fixing legumes. This integrated maize-livestock farming system is more labour-intensive and land-saving than the traditional farming system, in which livestock is grazed without much interaction with crop farming.

It is worth noting that this highly complex farming system is indigenous and evolved as the markets for milk, seeds and fertiliser developed and improved. It is a novel combination of technologies that has not been researched as a system, so the best combination of inputs and the optimum timing of their application is undocumented. 


\subsection{Rice}

This section focuses on a series of empirical studies of rice farming, based on household data collected in Mozambique (Chokwe irrigation scheme in the south and rainfed areas in the central region), Tanzania (three major rice-growing regions), Uganda (lowland rice-growing areas in the east and north), Ghana (rainfed areas in northern Ghana) and Senegal (irrigated areas in the Senegal River Valley), published in Otsuka and Larson (2016). In general, the surveys cover major lowland rice-growing areas in each country. As the studies reveal, lowland rice is a promising crop in Africa and one well suited to technologies currently used in Asia; however, the same is not true of upland rice, which is popular in West Africa. (Otsuka and Larson 2013; Estudillo and Otsuka 2013; Nakano et al. 2013).

In the Senegal River Valley, paddy yields average $4.5 \mathrm{t}$ per hectare, the highest among the five countries studied. Rice farmers in the Senegal River Valley have access to an irrigation facility with ample supply of water, adopt Asian-type semidwarf modern varieties, apply chemical fertilisers abundantly, and practise improved management such as bunding, levelling and straight-row planting (Sakurai 2016). Yields are comparable with yields observed in Asia's irrigated areas in the late 1980s (David and Otsuka 1994). Irrigated yields in Tanzania were lower, averaging $3.7 \mathrm{t}$ per hectare, partly because of lower-quality irrigation facilities and the incomplete adoption of improved management practices (Nakano et al. 2016). Irrigated yields in Mozambique ranged between 1.6 and $2.0 \mathrm{t}$ per hectare, well below the average of $2.2 \mathrm{t}$ in SSA (FAOSTAT 2015). This lower yield can be attributed to low-quality irrigation facilities, inadequate application of chemical fertiliser, use of old varieties, and low adoption of improved management practices (Kajisa 2016). Thus, it is clear that irrigation alone is not sufficient to achieve high rice yields. ${ }^{22}$

Njeru et al. (2016) observed paddy yield as high as $5 \mathrm{t}$ per hectare in the Mwea irrigation scheme in Kenya, where improved management practices were widely adopted, even though high-quality but low-yielding basmati varieties are grown. Rice markets are well developed there. Rice is strictly graded, and credits are available from credit unions and also from private traders. In some areas of the Mwea irrigation scheme, where varieties developed by the International Rice Research Institute (IRRI) are grown, yields of $8 \mathrm{t}$ per hectare were obtained. It is thus possible to achieve high yields in irrigated areas in Africa if improved varieties and chemical fertiliser are combined with improved management practices.

Nonetheless, achieving a sweeping revolution in rice will require improvements in rainfed rice yields, since $85 \%$ of lowland paddy field in SSA is rainfed (Balasubramanian et al. 2007). Rainfed yields ranged from 0.8 to $1.0 \mathrm{t}$ per hectare in Mozambique, $2.0 \mathrm{t}$ per hectare in Ghana and 2.3-2.5 $\mathrm{t}$ per hectare in Uganda. The higher average yields in Uganda are close to the average yield in rainfed areas in Asia in the late 1980s (David and Otsuka 1994). It is important to note that management training programmes were not implemented in Mozambique, but they were in rainfed areas

\footnotetext{
${ }^{22}$ Yield data in this paragraph are self-reported by farmers.
} 
in Uganda and Ghana. ${ }^{23}$ In rainfed areas in northern Ghana, yields averaged a mere $1.5 \mathrm{t}$ per hectare without any improved management practices, but reached $2.6 \mathrm{t}$ per hectare with the adoption of all recommended management practices, including use of improved seeds, chemical fertiliser, bunding, levelling and straight-row dibbling. Similarly, management training is found to be effective in rainfed areas in Uganda. It is noteworthy that substantial yield gains have been achieved, even in rainfed areas in SSA, without accompanying major market reforms or new investments in roads or irrigation systems. Moreover, if the markets work to support the improved rice farming system, further improvement in productivity can likely be achieved.

In Table 3, we turn to a broader measure of productivity and examine the effects of improved management practices on profitability, defined as the value of production per hectare minus paid-out cost and the imputed costs of owned resources evaluated at market prices. Because imputing the value of family labour is prone to error, the table also includes income per hectare, which is defined as the value of production minus paid-out cost per hectare. In Tanzania, both income and profit per hectare were significantly higher in irrigated areas compared to rainfed areas. In rainfed areas in Ghana, both income and profit per hectare were significantly higher for full adopters of improved seeds, fertiliser, bunding, levelling and dibbling than for nonadopters. In Uganda, income per hectare was significantly higher for management training participants. The Ugandan study also found that training participants adopted improved seeds, chemical fertiliser and improved management practices more often than non-participants. ${ }^{24}$

Table 3 Income and profit from rice cultivation, by status of training and technology adoption

\begin{tabular}{l|l|l|l}
\hline & Income per ha & Family labour cost per ha & Profit per ha \\
\hline Tanzania & & & \\
\hline Irrigated area & 1011 & 421 & 590 \\
\hline Rainfed area & 453 & 300 & 153 \\
\hline Uganda (rainfed) & & - & - \\
\hline Training participants & 1327 & - & - \\
\hline Non-participants & 905 & & 160 \\
\hline Ghana (rainfed) & & 215 & 59 \\
\hline Full adopters & 374 & 169 & \\
\hline Non-adopters & 228 & $(2016)$ & \\
\hline Sorces & & - & \\
\hline
\end{tabular}

Sources Kijima (2016), deGraft-Johnson et al. (2016), Nakano et al. (2016), Otsuka and Larson (2016). Note income and profit are measured in USD. Income is defined as the value of production minus paid-out costs. Profit is defined as income minus imputed costs of owned resources, including family labour

\footnotetext{
${ }^{23}$ No subsidy was provided in Uganda, whereas a subsidy for fertiliser and seeds was provided initially in Ghana around 2000.

${ }^{24}$ These results are robust when the treatment effects models were applied (Kijima 2016; deGraftJohnson et al. 2016).
} 
Considerable differences in income and profit between training participants and non-participants, and between full adopters and non-adopters, suggest that it is profitable to adopt seed-fertiliser-management (SFM) rice technology in SSA. Supporting evidence is provided by an ongoing study into the adoption of intensive rice cultivation systems in rainfed areas in Kilombero Valley in Tanzania by Nakano, Kajisa and Otsuka (2015), who also found significantly higher yields and profit per hectare associated with SFM technologies. Thus, returns on training programme seem very high, although rates of return have not been reported by these studies.

\section{Concluding Discussion}

Most rural development strategies in SSA focus on improving the productivity of smallholder farms. The approach has clear advantages, since it leverages resources already in place in rural communities - primarily land, family labour, farming knowledge and social capital—while the slow-paced dynamics of economic transformation and farm restructuring play out. Importantly, improving smallholder productivity speeds up economic growth and complements programmes that prepare rural workers for jobs in other sectors.

With the possible exception of mechanisation, technologies that improve overall small-farm productivity usually help farmers to achieve higher yields. In general, yield gaps are high in SSA and even a partial narrowing could have a significant impact on local and global food supplies. A careful and transparent approach to promoting new commercial farms, carved out from under-utilised land resources, can help to improve food supplies over time, but likely with fewer benefits for economic growth or poverty reduction and with greater stress on Africa's natural resources and ecologies.

A key instrument in the pursuit of improving smallholder productivity is the development and dissemination of new technologies. In the case of Asia's Green Revolution, a small set of technologies had a transformational impact on rural communities and food systems, which were land-constrained and structured largely around wheat and rice. In SSA, the agroclimatic and market conditions that support food systems are diverse. Consequently, a larger set of place-specific technologies are needed to prompt an African Green Revolution. This raises the cost of developing and testing new technologies and, importantly, the cost of disseminating technologies that meet farmers' needs.

Lessons from the fields of maize and rice farmers in SSA illustrate these points. In the case of lowland rice, the seed-fertiliser technologies that transformed many Asian food systems work successfully in well-managed irrigation systems and generate similar yields. However, the technologies are not enough to materially change the lives of most rice producers, since most of the rice produced in SSA is rainfed. Nevertheless, research suggests that, in many communities, rainfed rice yields can be improved by focusing not only on seeds and fertiliser, but on improved agronomic practices. It is worth keeping in mind that while the key technologies that drove Asia's 
Green Revolution relied on purchased inputs, they also leveraged available family labour. In places where input prices are high, ecologically intensive technologies, such as those based on improved agronomic and resource conservation practices, can further leverage family labour to achieve higher productivity levels with fewer purchased inputs.

In the case of maize, evolving differences in risk, markets and growing conditions help to explain dramatic differences among farmers in terms of use of fertiliser and high-yielding seeds. Heterogeneity also helps to explain why technology promotion programmes based on a single technology packet, which proved transformational in Asia, have seen limited success in Africa. However, as the example of highland maize farmers in Kenya illustrates, indigenous hybrid systems based on improved genetic material and improved resource management can supplement traditional seed-fertiliser technologies.

Taken together, all of this suggests that a strategy of boosting smallholder productivity is a sound one, especially when combined with policies that help families to prepare for jobs outside of agriculture. However, the task of building out, cataloguing and disseminating the full set of technologies needed for transformational change represents a challenge to African governments and the development community. However, there is evidence of local success and some indication that yield gaps have closed in recent years. Pursuing additional paths, built on resource management technologies and indigenous innovations, can speed Africa's Green Evolution.

Acknowledgements This article originally appeared under the title 'Why African rural development strategies must depend on small farms' in Global Food Security, Vol. 10 2016, pp. 39-51. The authors thank Global Food Security's editor, Derek Byerlee, and Elsevier for permission to republish the essay in this volume. The study itself is a result of a research project conducted at the Japan International Cooperation Agency (JICA) Research Institute to empirically analyse how best the Coalition for African Rice Development (CARD) initiative can serve to increase rice productivity and reduce poverty in SSA. CARD, which aimed to double rice production from 2008 to 2018, was jointly launched by JICA and the Alliance for the Green Revolution in Africa (AGRA) at the 4th Tokyo International Conference on African Development (TICAD) meeting in 2008. We would like to thank the JICA Research Institute for the intellectual and financial support it has provided for this project. We are also grateful for the financial support provided to maize research in Kenya by the Global Center of Excellence Program, the GRIPS Emerging State Project of the Japan Society for the Promotion of Science (JSPS KAKENHI Grant number 25101002) and the generous support of the donor-funded Knowledge for Change Program hosted by the World Bank.

\section{References}

Adesina, A. A., \& Baidu-Forson, J. (1995). Farmers' perceptions and adoption of new agricultural technology: Evidence from analysis in Burkina Faso and Guinea, West Africa. Agricultural Economics, 13(1), 1-9.

Akiyama, T., Baffes, J., Larson, D. F., \& Varangis, P. (2003). Commodity market reform in Africa: Some recent experience. Economics System, 27(1), 83-115. 
Alem, S., \& Pavlis, J. (2014). Conversion of grazing land into Grevillea robusta plantation and exclosure: Impacts on soil nutrients and soil organic carbon. Environmental Monitoring and Assessment, 186(7), 4331-4341.

Alene, A. D., Menkir, A., Ajala, S. O., Badu-Apraku, B., Olanrewaju, A. S., Manyong, V. M., et al. (2009). The economic and poverty impacts of maize research in West and Central Africa. Agricultural Economics, 40(5), 535-550.

Ali, D. A., \& Deininger, K. (2015). Is there a farm size-productivity relationship in African agriculture? Evidence from Rwanda. Land Economics, 91(2), 317-343.

Anderson, K. (2009). Distortions to agricultural versus nonagricultural producer incentives. Annual Review of Resource Economics, 1(1), 55-74.

Anderson, K., Cockburn, J., \& Martin, W. (Eds.). (2010). Agricultural price distortions, inequality, and poverty. Washington: World Bank.

Anderson, K., \& Brückner, M. (2012). Distortions to agriculture and economic growth in SubSaharan Africa (Policy Research Working Paper 6206). Washington: World Bank.

Andrae, G., \& Beckman, B. (1985). The wheat trap: Bread and underdevelopment in Nigeria. London and Uppsala: Scandinavian Institute for African Studies, Zed Books Ltd.

Anríquez, G., \& López, R. (2007). Agricultural growth and poverty in an archetypical middle income country: Chile 1987-2003. Agricultural Economics, 36(2), 191-202.

Arezki, R., Deininger, K., \& Selod, H. (2015). What drives the global "land rush"? The World Bank Economic Review, 29(2), 207-233.

Assunção, J. J., \& Braido, L. H. (2007). Testing household-specific explanations for the inverse productivity relationship. American Journal of Agricultural Economics, 89(4), 980-990.

Balasubramanian, V., Sie, M., Hijmans, R. J., \& Otsuka, K. (2007). Increasing rice production in Sub-Saharan Africa: Challenges and opportunities. Advances in Agronomy, 94, 55-133.

Barrett, C. B. (1996). On price risk and the inverse farm size-productivity relationship. Journal of Development Economics, 51(2), 193-215.

Barrett, C. B., Bellemare, M. F., \& Hou, J. Y. (2010). Reconsidering conventional explanations of the inverse productivity-size relationship. World Development, 38(1), 88-97.

Bautista, R. M., \& Valdés, A. (1993). The bias against agriculture: Trade and macroeconomic policies in developing countries. San Francisco: International Centre for Economic Growth.

Benin, S., \& Yu, B. (2013). Trends in public agricultural expenditures in Africa. Washington: International Food Policy Research Institute (ReSAKSS Issue Note 22).

Benjamin, D. (1995). Can unobserved land quality explain the inverse productivity relationship? Journal of Development Economics, 46(1), 51-84.

Berry, A. (1984). Land reform and the adequacy of world food production. In J. Montgomery (Ed.), International dimensions of land reform. Boulder: Westview Press.

Bezu, S., Barrett, C. B., \& Holden, S. T. (2012). Does the nonfarm economy offer pathways for upward mobility? Evidence from a panel data study in Ethiopia. World Development, 40(8), 1634-1646.

Bezu, S., Kassie, G. T., \& Shiferaw, B. (2014). Impact of improved maize adoption on welfare of farm households in Malawi: A panel data analysis. World Development, 59, 120-131.

Bhalla, S. S., \& Roy, P. (1988). Mis-specification in farm productivity analysis: The role of land quality. Oxford Economic Papers, 40(1), 55-73.

Bardhan, P., \& Mookherjee, D. (2006). Land reform, decentralized governance, and rural development in West Bengal. In Conference on Challenges of Economic Policy Reform in Asia (Vol. 31).

Binswanger, H., \& Rosenzweig, M. (1981). Contractual arrangements, employment and wages in rural labor markets: A critical review (Studies in employment and rural development No. 67). Washington: World Bank.

Binswanger, H., Deininger, K., \& Feder, M. (1993). Power, distortions, revolt and reform in agricultural land relations (Policy Research Working Paper 1164). World Bank, Washington. 
Binswanger-Mkhize, H., \& McCalla, A. F. (2010). The changing context and prospects for agricultural and rural development in Africa. In P. Pingali \& R. Evenson (Eds.), Handbook of agricultural economics. Amsterdam: Elsevier.

Borras, S. M., Jr., Hall, R., Scoones, I., White, B., \& Wolford, W. (2011). Towards a better understanding of global land grabbing: An editorial introduction. Journal of Peasant Studies, 38(2), 209-216.

Bravo-Ortega, C., \& Lederman, D. (2009). La agricultura y el bienestar nacional en el mundo. El Trimestre Economico, 76(3), 577-617.

Brinkley, D. (1996). Bringing the Green Revolution to Africa: Jimmy Carter, Norman Borlaug, and the Global 2000 Campaign. World Policy J., 13(1), 53-62.

Bruinsma, J. (2009). The resources outlook: By how much do land, water and crop yields need to increase by 2050? In P. Conforti (Ed.), Looking ahead in world food and agriculture: Perspectives to 2050. Rome: Food and Agriculture Organization.

Butzer, R., Mundlak, Y., \& Larson, D. F. (2003). Intersectoral migration in Southeast Asia: Evidence from Indonesia, Thailand, and the Philippines. Journal of Agricultural and Applied Economics, 35(Supplement), S105-S117.

Byerlee, D., Masters, W. A., \& Robinson, D. (2017). From land grab to land development: Unlocking the potential for private investment to support small-holder farms in frontier areas. In P. Pengali \& G. Feder (Eds.), Agriculture and rural development in a globalizing world: Challenges and opportunities. London and New York: Routledge.

Byiringiro, F., \& Reardon, T. (1996). Farm productivity in Rwanda: Effects of farm size, erosion, and soil conservation investments. Agricultural Economics, 15(2), 127-136.

Carletto, C., Savastano, S., \& Zezza, A. (2013). Fact or artifact: The impact of measurement errors on the farm size-productivity relationship. Journal of Development Economics, 103, 254-261.

Carter, M. R. (1984). Identification of the inverse relationship between farm size and productivity: An empirical analysis of peasant agricultural production. Oxford Economic Papers, 36(1), 131-145.

Christiaensen, L., Demery, L., \& Kuhl, J. (2011). The (evolving) role of agriculture in poverty reduction: An empirical perspective. Journal of Development Economics, 96(2), 239-254.

Cobo, J. G., Dercon, G., \& Cadisch, G. (2010). Nutrient balances in African land use systems across different spatial scales: A review of approaches, challenges and progress. Agriculture, Ecosystems \& Environment, 136(1), 1-15.

Coeymans, J. E., \& Mundlak, Y. (1992). Endogenous technology and sectoral productivity: Chile 1962-1982. The Journal of Productivity Analysis, 3(3), 257-275.

Collier, P., \& Venables, A. J. (2012). Land deals in Africa: Pioneers and Speculators (Ox-Carre Research Paper 69). Oxford: Oxford University.

Collier, P., \& Dercon, S. (2014). African agriculture in 50 years: Smallholders in a rapidly changing world? World Development, 63, 92-101.

Cornia, G. A. (1985). The social costs and benefits of biofuels: The intersection of environmental, energy and agricultural policy. Applied Economic Perspectives and Policy, 13(4), 513-534.

Crawford, E., Kelly, V., Jayne, T. S., \& Howard, J. (2003). Input use and market development in Sub-Saharan Africa: An overview. Food Policy, 28(4), 277-292.

Dao, A., Sanou, J., Gracen, V., \& Danquah, E. Y. (2015). Identifying farmers' preferences and constraints to maize production in two agroecological zones in Burkina Faso. Agriculture Food Security, 4(1), 1-7.

David, C. C., \& Otsuka, K. (1994). Modern rice technology and income distribution in Asia. Boulder, CO: Lynne Rienner.

deGraft-Johnson, M., Suzuki, A., Sakurai, T., \& Otsuka, K. (2016). 5 On the possibility of rice green revolution in rainfed areas in northern Ghana: An assessment of a management training program. In K. Otsuka \& D. F. Larson (Eds.), In pursuit of an African Green Revolution: Views from rice, maize farmers fields. Tokyo: Springer.

Deininger, K., \& Byerlee, D. (2012). The rise of large farms in land abundant countries: Do they have a future? World Development, 40(4), 701-714. 
Deininger, K., Hilhorst, T., \& Songwe, V. (2014). Identifying and addressing land governance constraints to support intensification and land market operation: Evidence from 10 African countries. Food Policy, 48, 76-87.

Deininger, K., Byerlee, D., Lindsay, J., Norton, A., Selod, H., \& Stickler, M. (2011). Rising global interest in Farmland: Can it yield sustainable and equitable benefits?. Washington: World Bank.

Delgado, C., Narrod, C., \& Tiongco, M. (2008). Determinants and implications of the growing scale of livestock farms in four fast-growing developing countries (Research Report 157). Washington: International Food Policy Research Institute.

Dercon, S. (2013). Agriculture and development: Revisiting the policy narratives. Agricultural Economics, 44(S1), 183-187.

Dethier, J. J., \& Effenberger, A. (2012). Agriculture and development: A brief review of the literature. Economic Systems, 36(2), 175-205.

Deugd, M., Röling, N., \& Smaling, E. M. A. (1998). A new praxeology for integrated nutrient management, facilitating innovation with and by farmers. Agriculture, Ecosystems \& Environment, 71(1-3), 269-283.

Diagne, A., Midingoyi, S. K. G., \& Kinkingninhoun-Medagbe, F. M. (2013). Impact of NERICA adoption on rice yield: Evidence from West Africa. In K. Otsuka \& D. F. Larson (Eds.), An African Green Revolution. Dordrecht: Springer.

Diao, X., Hazell, P. B. R., \& Thurlow, J. (2010). The role of agriculture in African development. World Development, 38(10), 1375-1383.

Djurfeldt, A. A., \& Djurfeldt, G. (2013). Structural transformation and African smallholders: Drivers of mobility within and between the farm and non-farm sectors for eight countries. Oxford Development Studies, 41(3), 281-306.

Dorosh, P., \& Thurlow, J. (2014). Can cities or towns drive African development? Economy wide analysis for Ethiopia and Uganda. World Development, 63, 113-123.

Drechsel, P., Gyiele, L., Kunze, D., \& Cofie, O. (2001). Population density, soil nutrient depletion, and economic growth in Sub-Saharan Africa. Ecological Economics, 38(2), 251-258.

Drèze, J., \& Sen, A. K. (1989). Hunger and public action. Oxford: Oxford University Press.

Duflo, E., Kremer, M., \& Robinson, J. (2008). How high are rates of return to fertilizer? Evidence from field experiments in Kenya. American Economic Review, 98(2), 482-488.

Dzanku, F. M., Jirström, M., \& Marstorp, H. (2015). Yield gap-based poverty gaps in rural subSaharan Africa. World Development, 67, 336-362.

Eastwood, R., Lipton, M., \& Newell, A. (2010). Farm size. In P. L. Pingali \& R. E. Evenson (Eds.), Handbook of agricultural economics. Elsevier, Amsterdam: North Holland.

Eicher, C. K., \& Baker, D. C. (1982). Research on agricultural development in Sub-Saharan Africa: a critical survey (MSU International Development Paper 1). East Lansing: Michigan State University.

Estudillo, J. P., \& Otsuka, K. (2013). Lessons from the Asian Green Revolution in Rice. In K. Otsuka \& D. F. Larson (Eds.), An African Green Revolution: Finding ways to boost productivity on small farms. Dordrecht: Springer.

Evenson, R. E., \& Gollin, D. (2003a). Assessing the impact of the Green Revolution, 1960-2000. Science, 300(5620), 758-762.

Evenson, R. E., \& Gollin, D. (2003b). Crop genetic improvement in developing countries: Overview and summary. In R. E. Evenson \& D. Gollin (Eds.), Crop variety improvement and its effect on productivity: The impact of international agricultural research. Cambridge, MA: CABI Publishing.

Evenson, R. E., \& Gollin, D. (2003c). Crop variety improvement and its effect on productivity: The impact of international agricultural research. Cambridge, MA: CABI Publishing.

Fan, S., \& Chan-Kang, C. (2005). Is small beautiful? Farm size, productivity, and poverty in Asian agriculture. Agricultural Economics, 32(s1), 135-146.

FAO. (2017). Rural Africa in motion. Dynamics and drivers of migration South of the Sahara. Rome: Food and Agriculture Organization. http://www.fao.org/3/I7951EN/i7951en.pdf. 
FAOSTAT. (2015). Food and agriculture organization corporate statistical database. Rome: Food and Agriculture Organization.

Feder, G. (1985). The relation between farm size and farm productivity: The role of family labor, supervision and credit constraints. Journal of Development Economics, 18(2), 297-313.

Fischer, G. (2009). How can climate change and the development of bioenergy alter the long-term outlook for food and agriculture? Rome: Food and Agriculture Organization. Available at: http:// www.fao.org/3/a-ak972e.pdf.

Fox, L., Haines, C., Muñoz, J. H., \& Thomas, A. H. (2013). Africa's got work to do: Employment prospects in the new century (IMF Working Paper 13/201). Washington: International Monetary Fund.

Frelat, R., Lopez-Ridaura, S., Giller, K. E., Herrero, M., Douxchamps, S., Djurfeldt, A. A., et al. (2016). Drivers of household food availability in Sub-Saharan Africa based on big data from small farms. Proceedings of National Academy of Sciences, 113(2), 458-463.

Gardner, B. L. (2000). Economic growth and low incomes in agriculture. American Journal of Agricultural Economics, 82(5), 1059-1074.

Godfray, H. C. J., Beddington, J. R., Crute, I. R., Haddad, L., Lawrence, D., Muir, J. F., et al. (2010a). Food security: The challenge of feeding 9 billion people. Science, 327(5967), 812-818.

Godfray, H. C. J., Crute, I. R., Haddad, L., Lawrence, D., Muir, J. F., Nisbett, N., et al. (2010b). The future of the global food system. Philosophical Transactions of the Royal Society of London. Series B, Biological sciences, 365(1554), 2769-2777.

de Gorter, H., \& Just, D. R. (2010). The social costs and benefits of biofuels: The intersection of environmental, energy and agricultural policy. Applied Economic Perspectives and Policy, 32(1), 4-32.

de Groote, H., Siambi, M., Friesen, D., \& Diallo, A. (2002). Identifying farmers' preferences for new maize varieties in eastern Africa. In M. R. Bellon \& J. R. Reeves (Eds.), Quantitative analysis of data from participatory methods in plant breeding. Mexico City: CIMMYT.

Haggblade, S., \& Hazell, P. B. R. (2010). Successes in African agriculture: Lessons for the future. Baltimore: The Johns Hopkins University Press.

Haggblade, S., Hazell, P. B. R., \& Reardon, T. (2010). The rural non-farm economy: Prospects for growth and poverty reduction. World Development, 38(10), 1429-1441.

Hall, A. J., \& Richards, R. A. (2013). Prognosis for genetic improvement of yield potential and water-limited yield of major grain crops. Field Crops Res., 143, 18-33.

Hawkesford, M. J., Araus, J. L., Park, R., Calderini, D., Miralles, D., Shen, T., et al. (2013). Prospects of doubling global wheat yields. Food Energy Security, 2(1), 34-48.

Hayami, Y., \& Kikuchi, M. (2000). A rice village saga: Three decades of Green, Revolution in the Philippines. London: Macmillan Press Ltd.

Hayami, Y., Quisumbing, A. R., \& Adriano, L. (1990). Towards an alternative land reform paradigm: A Philippine, perspective. Manila: Ateneo de Manila University Press.

Hazell, P. B. R. (2009). Transforming agriculture: The Green Revolution in Asia. In D. Spielman \& R. Pandya-Lorch (Eds.), Millions Fed: Proven successes in agricultural development. Washington: International Food Policy Research Institute.

Hazell, P. B. R., Poulton, C., Wiggins, S., \& Dorward, A. (2010). The future of small farms: Trajectories and policy priorities. World Development, 38(10), 1349-1361.

Hossain, M. (1977). Farm size, tenancy and land productivity: An analysis of farm level data in Bangladesh agriculture. Bangladesh Development Studies, 5(3), 285-348.

Howard, J., Crawford, E., Kelly, V., Demeke, M., \& Jeje, J. J. (2003). Promoting high-input maize technologies in Africa: The Sasakawa-Global 2000 experience in Ethiopia and Mozambique. Food Policy, 28(4), 335-348.

IPCC. (2014). Intergovernmental panel on climate change. Climate change 2014: Impacts, adaptation, and vulnerability. Available on the internet at: https://www.ipcc.ch/report/ar5/wg2/.

Irz, X., Lin, L., Thirtle, C., \& Wiggins, S. (2001). Agricultural productivity growth and poverty alleviation. Development Policy Review, 19(4), 449-466. 
de Janvry, A., \& Sadoulet, E. (2010). Agricultural growth and poverty reduction: Additional evidence. The World Bank Research Observer, 25(1), 1-20.

Jayne, T., \& Rashid, S. (2013). Input subsidy programs in Sub-Saharan Africa: A synthesis of recent evidence. Agricultural Economics, 44(6), 547-562.

Jeon, Y. D., \& Kim, Y. Y. (2000). Land reform, income redistribution, and agricultural production in Korea. Economic Development and Cultural Change, 48(2), 253-268.

Jayne, T. S., Chamberlin, J., \& Headey, D. D. (2014). Land pressures, the evolution of farming systems, and development strategies in Africa: A synthesis. Food Policy, 48, 1-17.

Jayne, T. S., Govereh, J., Wanzala, M., \& Demeke, M. (2003). Fertilizer market development: A comparative analysis of Ethiopia, Kenya, and Zambia. Food Policy, 28(4), 293-316.

Johnson, M., Hazell, P., \& Gulati, A. (2003). The role of intermediate factor markets in Asia's Green Revolution: Lessons for Africa? American Journal of Agricultural Economics, 85(5), 1211-1216.

Johnston, B. F., \& Cownie, J. (1969). The seed-fertilizer revolution and labor force absorption. American Economic Review, 59(4), 569-582.

Kajisa, K. (2016). On the determinants of low productivity of rice farming in Mozambique: Pathways to intensification. In K. Otsuka \& D. F. Larson (Eds.), In pursuit of an African Green Revolution: Views from rice, maize farmers' fields. Tokyo: Springer.

Kajisa, K., \& Palanichamy, N. V. (2013). Chemical fertilizer, organic fertilizer, and cereal yields in India. In K. Otsuka \& D. F. Larson (Eds.), An African Green Revolution: Finding ways to boost productivity on small farms. Dordrecht: Springer.

Khonje, M., Manda, J., Alene, A. D., \& Kassie, M. (2015). Analysis of adoption and impacts of improved maize varieties in Eastern Zambia. World Development, 66, 695-706.

Khush, G. S. (2013). Strategies for increasing the yield potential of cereals: Case of rice as an example. Plant Breeding, 132(5), 433-436.

Kijima, Y. (2016). On the possibility of Rice Green Revolution in rainfed areas in Uganda: Impact evaluation of a management training program and guidebook distribution. In K. Otsuka \& D. F. Larson (Eds.), In pursuit of an African Green Revolution: Views from rice and maize farmers' fields. Tokyo: Springer.

Kimhi, A. (2006). Plot size and maize productivity in Zambia: Is there an inverse relationship? Agricultural Economics, 35(1), 1-9.

Kostandini, G., Rovere, R. L., \& Abdoulaye, T. (2013). Potential impacts of increasing average yields and reducing maize yield variability in Africa. Food Policy, 43, 213-226.

Kumar, S. (1979). Impact of subsidised rice on food consumption and nutrition in Kerala Research Report 5. Washington: International Food Policy Research Institute.

Kutcher, G., \& Scandizzo, P. L. (1981). The agricultural economy of North-East Brazil. Baltimore: World Bank and Johns Hopkins University Press.

Lamb, R. L. (2003). Inverse productivity: Land quality, labor markets, and measurement error. Journal of Development Economics, 71(1), 71-95.

Langyintuo, A. S., Mwangi, W., Diallo, A. O., MacRobet, J., Dixon, J., \& Bänziger, M. (2010). Challenges of the maize seed industry in eastern and southern Africa: A compelling case for private-public intervention to promote growth. Food Policy, 35(4), 323-331.

Larson, D. F., \& Mundlak, Y. (1997). On the intersectoral migration of agricultural labor. Economic Development and Cultural Change, 45(2), 295-319.

Larson, D. F., \& Leon, M. (2006). How endowments, accumulations, and choice determine the geography of agricultural productivity in Ecuador. The World Bank Economic Review, 20(3), $449-471$.

Larson, D. F., \& Gurara, D. Z. (2013). A conceptual model of incomplete markets and the consequences for technology adoption policies in Ethiopia (Policy Research Working Paper 6681). Washington: World Bank.

Larson, D. F., Anderson, J. R., \& Varangis, P. (2004). Policies on managing risk in agricultural markets. The World Bank Research Observer, 19(2), 199-230. 
Larson, D. F., Otsuka, K., Matsumoto, T., \& Kilic, T. (2014). Should African rural development strategies depend on smallholder farms? An exploration of the inverse-productivity hypothesis. Agricultural Economics, 45(3), 355-367.

Larson, D. F., Savastano, S., Murray, S., \& Palacios-Lopez, A. (2016). Are women less productive farmers? How markets and risk affect fertilizer use, productivity, and measured gender effects in Uganda. In K. Otsuka \& D. F. Larson (Eds.), In pursuit of an African Green Revolution: Views from rice and maize farmers' fields. Tokyo: Springer.

Lipton, M. (2006). Can small farmers survive, prosper, or be the key channel to cut mass poverty. Electron. Journal of Development and Agricultural Economics, 3(1), 58-85.

Lipton, M. (2009). Land reform in developing countries: Property rights and property wrongs. London: Routledge.

Lipton, M. (2012). Learning from others: Increasing agricultural productivity for human development in Sub-Saharan Africa United Nations Development Programme Regional Bureau for Africa (Working Paper 2012-007). New York: United Nations.

Lobell, D. B., Cassman, K. G., \& Field, C. B. (2009). Crop yield gaps: Their importance, magnitudes and causes. Annual Review of Environment and Resources, 34(1), 179-204.

Lowder, S. K., Skoet, J., \& Singh, S. (2014). What do we really know about the number and distribution of farms and family farms in the world? (ESA Working Paper 14-02). Rome: Food and Agriculture Organization.

Lowder, S. K., Skoet, J., \& Raney, T. (2016). The number, size, and distribution of farms, smallholder farms, and family farms worldwide. World Development, 87, 16-29.

Lunduka, R., Fisher, M., \& Snapp, S. (2012). Could farmer interest in a diversity of seed attributes explain adoption plateaus for modern maize varieties in Malawi? Food Policy, 37(5), 504-510.

Marenya, P., \& Barrett, C. (2007). Household-level determinants of adoption of improved natural resources management practices among smallholder farmers in western Kenya. Food Policy, 32(4), 515-536.

Marenya, P., \& Barrett, C. (2009). State-conditional fertilizer yield response on Western Kenyan farms. American Journal of Agricultural Economics, 91(4), 991-1006.

Masters, W. A., Djurfeldt, A. A., De Haan, C., Hazell, P., Jayne, T., Jirström, M., et al. (2013). Urbanization and farm size in Asia and Africa: Implications for food security and agricultural research. Global Food Security, 2(3), 156-165.

Mathenge, M. K., Smale, M., \& Olwande, J. (2014). The impacts of hybrid maize seed on the welfare of farming households in Kenya. Food Policy, 44, 262-271.

Matsumoto, T., \& Yamano, T. (2013). Maize, soil fertility, and the Green Revolution in East Africa. In K. Otsuka \& D. F. Larson (Eds.), An African Green Revolution: Finding ways to boost productivity on small farms. Dordrecht: Springer.

Maxwell, S., \& Slater, R. (2003). Food policy old and new. Development Policy Review, 21(5-6), 531-553.

McDermott, J. J., Staal, S. J., Freeman, H. A., Herrero, M., \& Van de Steeg, J. A. (2010). Sustaining intensification of smallholder livestock systems in the tropics. Livestock Science, 130(1), 95-109.

Meadows, D. H., Meadows, D. L., Randes, J., \& Behrens, W. W. (1972). The limits to growth. New York: Universe Book.

Morris, M., Kelly, V., Kopicki, R., \& Byerlee, D. (2007). Fertilizer use in African Agriculture: Lessons learned and good practice guidelines. Washington, D.C.: World Bank.

Moseley, W. G., Carney, J., \& Becker, L. (2010). Neoliberal policy, rural livelihoods, and urban food security in West Africa: A comparative study of The Gambia, Côte d' Ivoire, and Mali. Proceedings of National Academy of Sciences, 107(13), 5774-5779.

Mueller, N. D., Gerber, J. S., Johnston, M., Ray, D. K., Ramankutty, N., \& Foley, J. A. (2012). Closing yield gaps through nutrient and water management. Nature, 490(7419), 254-257.

Mundlak, Y. (1988). Endogenous technology and the measurement of productivity. In S. M. Capalbo \& J. M. Antle (Eds.), Agricultural productivity: Measurement and explanation. Washington: Resources for the Future. 
Mundlak, Y., Cavallo, D., \& Domenech, R. (1989). Agriculture and economic growth in Argentina, 1913-84 (Research Report 76). Washington: International Food Policy Research Institute.

Mundlak, Y., Butzer, R., \& Larson, D. F. (2012). Heterogeneous technology and panel data: The case of the agricultural production function. Journal of Development Economics, 99(1), 139-149.

Muraoka, R., Matsumoto, T., Jin, S., \& Otsuka, K. (2016). On the possibility of a maize green revolution in the highlands of Kenya: An assessment of emerging intensive farming systems. In K. Otsuka \& D. F. Larson (Eds.), In pursuit of an African Green Revolution: Views from rice and maize farmers' fields. Tokyo: Springer.

Nakano, Y., Kajisa, K., \& Otsuka, K. (2015). To what extent does modified system of rice intensification (SRI) training increase productivity of small-scale cultivation in a rain-fed area? Evidence from Tanzania. Tokyo, Japan: National Graduate Institute for Policy Studies, Mimeo,

Nakano, Y., Kajisa, K., \& Otsuka, K. (2016). On the possibility of rice green revolution in irrigated and rainfed areas in Tanzania: An assessment of management training and credit programs. In K. Otsuka \& D. F. Larson (Eds.), In pursuit of an African Green Revolution: Views from rice and maize farmers' fields. Tokyo: Springer.

Nakano, Y., Bamba, I., Diagne, A., Otsuka, K., \& Kajisa, K. (2013). The possibility of a rice Green Revolution in large-scale irrigation schemes in Sub-Saharan Africa. In K. Otsuka \& D. F. Larson (Eds.), An African Green Revolution: Finding ways to boost productivity on small farms. Dordrecht: Springer.

Nega, B., Adenew, B., \& Gebre Sellasie, S. (2003). Current Land policy issues Ethiop. Land Reform, Land Settlement and Cooperatives, 11(3), 103-124.

Neumann, K., Verburg, P. H., Stehfest, E., \& Müller, C. (2010). The yield gap of global grain production: A spatial analysis. Agricultural Systems, 103(5), 316-326.

Njeru, T. N., Mano, Y., Otsuka, K. (2016, forthcoming). Role of access to credit in rice production in Sub Saharan Africa: The case of Mwea irrigation scheme in Kenya. Journal of African Economies, 25(2), 300-321.

Nkonya, E., Pender, J., Jagger, P., Sserunkuuma, R., Kaissi, C., \& Ssali, H. (2004). Strategies for sustainable land management and poverty reduction in Uganda Research Report 133. Washington: International Food Policy Research Institute.

Norgrove, L., \& Hauser, S. (2016). Biophysical criteria used by farmers for fallow selection in West and Central Africa. Ecological Indicators, 61, 141-147.

Ojiem, J., Franke, A., Vanlauwe, B., de Ridder, N., \& Giller, K. (2014). Benefits of legume-maize rotations: Assessing the impact of diversity on the productivity of smallholders in Western Kenya. Field Crops Research, 168, 75-85.

Otsuka, K., \& Yamano, T. (2005). The possibility of a Green Revolution in Sub-Saharan Africa: evidence from Kenya. Journal of Development and Agricultural Economics, 2(1), 7-19.

Otsuka, K., \& Yamano, T. (2006). Introduction to the special issue on the role of non-farm income in poverty reduction: evidence from Asia, East Africa. Agricultural Economics, 35(s3), 393-397.

Otsuka, K., \& Larson, D. F. (2013). An African Green Revolution: Finding ways to boost productivity on small farms. Dordrecht: Springer.

Otsuka, K., \& Larson, D. F. (2016). In pursuit of an African Green Revolution: Views from rice and maize farmers' fields. Tokyo: Springer.

Otsuka, K., Liu, Y., \& Yamauchi, F. (2016). Growing advantage of large farms in Asia and its implications for global food security. Global Food Security, 11, 5-10.

Otsuka, K., \& Place, F. (2015). Land tenure and agricultural intensification in Sub-Saharan Africa. In C. Monga \& J. Y. Lin (Eds.), The Oxford handbook of Africa and economics: Volume 2: Policies and practices. Oxford: Oxford University Press.

Pardey, P. G., Beintema, N., Dehmer, S., \& Wood, S. (2006). Agricultural research: A growing global divide?. Washington: International Food Policy Research Institute.

de Paul Obade, V., \& Lal, R. (2013). Assessing land cover and soil quality by remote sensing and geographical information systems (GIS). CATENA, 104, 77-92.

Pingali, P. L. (2012). Green Revolution: Impacts, limits, and the path ahead. Proceedings of National Academy of Sciences, 109(31), 12302-12308. 
Pingali, P. L., \& Rosegrant, M. W. (1994). Confronting the environmental consequences of the Green Revolution in Asia (EPDT Discussion Paper 2). Washington: International Food Policy Research Institute.

Pinstrup-Andersen, P., \& Hazell, P. B. (1985). The impact of the Green Revolution and prospects for the future. Food Reviews International, 1(1), 1-25.

Place, F., Barrett, C., Freeman, H. A., Ramisch, J. J., \& Vanlauwe, B. (2003). Prospects for integrated soil fertility management using organic and inorganic inputs: Evidence from smallholder African agricultural systems. Food Policy, 28(4), 365-378.

Popkin, B. M. (1998). The nutrition transition and its health implications in lower-income countries. Public Health Nutrition, 1(01), 5-21.

Poulton, C., Kydd, J., \& Dorward, A. (2006). Overcoming market constraints on pro-poor agricultural growth in Sub-Saharan Africa. Development Policy Review, 24(3), 243-277.

Ray, D. K., Mueller, N. D., West, P. C., \& Foley, J. A. (2013). Yield trends are insufficient to double global crop production by 2050. PLoS ONE, 8(6), e66428.

Ray, D. K., Ramankutty, N., Mueller, N. D., West, P. C., \& Foley, J. A. (2012). Recent patterns of crop yield growth and stagnation. Nature Communications, 3, 1297. https://doi.org/10.1038/ ncomms2296.

Reij, C. P., \& Smaling, E. M. A. (2008). Analyzing successes in agriculture and land management in Sub-Saharan Africa: Is macro-level gloom obscuring positive micro-level change? Land Use Policy, 25(3), 410-420.

Ricker-Gilbert, J., Mason, N. M., Darko, F. A., \& Tembo, S. T. (2013). What are the effects of input subsidy programs on maize prices? Evidence from Malawi and Zambia. Agricultural Economics, 44(6), 671-686.

Rosegrant, M. W., \& Hazell, P. B. R. (2000). Transforming the Rural Asian Economy: The Unfinished Revolution. Hong Kong: Oxford University Press.

Sakurai, T. (2016). On the determinants of high productivity in rice farming in irrigated areas in Senegal: Efficiency of large-scale vs. small-scale irrigation schemes. In K. Otsuka \& D. F. Larson (Eds.), In pursuit of an African Green Revolution: Views from rice and maize farmers' fields. Tokyo: Springer.

Satterthwaite, D., McGranahan, G., \& Tacoli, C. (2010). Urbanization and its implications for food and farming. Philosophical Transactions of the Royal Society of London. Series B, Biological Sciences, 365(1554), 2809-2820.

Searchinger, T. D., Estes, L., Thornton, P. K., Beringer, T., Notenbaert, A., Rubenstein, D., et al. (2015). High carbon and biodiversity costs from converting Africa's wet savannahs to cropland. Nature Climate Change, 5(5), 481-486.

Singh, B. (1985). Agrarian structure. Agricole, New Delhi: Technological Change and Poverty.

Sen, A. K. (1966). Peasants and dualism with or without surplus labor. Journal of Political Economy, 74(5), 425-450.

Sheahan, M., Black, R., \& Jayne, T. (2013). Are Kenyan farmers underutilizing fertilizer? Implications for input intensification strategies and research. Food Policy, 41, 39-52.

Smale, M. (1994). Maize is life: Malawi's delayed Green Revolution. World Development, 23(5), 819-831.

Smale, M., \& Jayne, T. S. (2010). Seeds of success in retrospect: Hybrid maize in Eastern and Southern Africa. In S. Haggblade \& P. B. R. Hazell (Eds.), Successes in African Agriculture: Lessons for the future. Washington: International Food Policy Research Institute.

Smale, M., Byerlee, D., \& Jayne, T. (2013). Maize revolution in Sub-Saharan Africa. In K. Otsuka \& D. F. Larson (Eds.), An African Green Revolution: Finding ways to boost productivity on small farms. Dordrecht: Springer.

Smale, M., Moursi, M., \& Birol, E. (2015). How does adopting hybrid maize affect dietary diversity on family farms? Micro-evidence from Zambia. Food Policy, 52, 44-53.

Snapp, S., Blackie, M., Gilbert, R., Bezner-Kerr, R., \& Kanyama-Phiri, G. (2010). Biodiversity can support a Greener Revolution in African. Proceedings National Academy of Sciences, 107(48), 20840-20845. 
Srinivasan, T. N. (1972). Farm size and productivity implications of choice under uncertainty. Sankhyā: Indian. Journal of the Royal Statistical Society: Series B, 34(4), 409-420.

Stevenson, J. R., Villoria, N., Byerlee, D., Kelley, T., \& Maredia, M. (2013). Green Revolution research saved an estimated 18 to 27 million hectares from being brought into agricultural production. Proceedings of National Academy of Sciences, 110(21), 8363-8368.

Suri, T. (2011). Selection and comparative advantage in technology adoption. Econometorica, 79(1), 159-209.

Thornton, P. K. (2010). Livestock production: Recent trends future prospects. Philosophical Transactions of the Royal Society of London. Series B, Biological sciences, 365(1554), $2853-2867$.

Timmer, C. P. (1997). Building efficiency in agricultural marketing: The long-run role of BULOG in the Indonesian food economy. Journal of International Development, 9(1), 133-146.

Tittonell, P., \& Giller, K. E. (2013). When yield gaps are poverty traps: The paradigm of ecological intensification in African smallholder agriculture. Field Crops Res., 143, 76-90.

Tripp, R. (1993). Invisible hands, indigenous knowledge and inevitable fads: Challenges to public sector agricultural research in Ghana. World Development, 21(12), 2003-2016.

United Nations. (2018). World urbanization prospects, The 2018 Revision. New York: Department of Economic and Social Affairs, United Nations.

Vollrath, D. (2007). Land distribution and international agricultural productivity. American Journal of Agricultural Economics, 89(1), 202-216.

van Zyl, J., Binswanger, H., \& Thirtle, C., (1995). The relationship between farm size and efficiency in South African Agriculture (Policy Research Working Paper 1548). Washington: World Bank.

Wiggins, S., Kirsten, J., \& Llambí, L. (2010). The future of small farms. World Development, 38(10), 1341-1348.

Winter-Nelson, A., \& Temu, A. (2005). Impacts of prices and transactions costs on input usage in a liberalizing economy: Evidence from Tanzanian coffee growers. Agricultural Economics, 33(3), 243-253.

World Bank. (2015). Commodity markets outlook October 2015. Washington: World Bank.

World Bank Pink Sheet. (2015). Global economic monitor commodities. Available at: http:// databank.worldbank.org/data/databases/commodity-price-data.

Xu, Z., Guan, Z., Jayne, T. S., \& Black, R. (2009). Profitability of applying fertilizer on maize for smallholder farmers in Zambia. Agricultural Economics, 40(4), 437-446.

Yamauchi, F., \& Larson, D. F. (2016). Long-term impacts of an unanticipated risk event: The 2007/08 food price crisis and child growth in Indonesia (World Bank Policy Research Working Paper 7627). Washington: World Bank.

Yotopoulos, P. A., \& Lau, L. J. (1973). A test for relative economic efficiency: Some further results. American Economic Review, 63(1), 214-223.

Zeng, D., Alwang, J., Norton, G. W., Shiferaw, B., Jaleta, M., \& Yirga, C. (2015). Ex post impacts of improved maize varieties on poverty in rural Ethiopia. Agricultural Economics, 46(4), 1-12.

Zerfu, D., \& Larson, D. F. (2010). Incomplete markets and fertilizer use: Evidence from Ethiopia (World Bank Policy Research Working Paper Series 5235). Washington: World Bank.

Zoomers, A. (2010). Globalisation, the foreignisation of space: Seven processes driving the current global land grab. Journal of Peasant Studies, 37(2), 429-447.

Dr. Donald F. Larson is an independent researcher and founder of the International Institute for Development and Environmental Studies, formerly senior economist in the Development Research Group at the World Bank. He also holds a courtesy faculty position at William and Mary's Global Research Institution. He holds a Ph.D. in agricultural and resource economics from the University of Maryland, USA, as well as degrees in economics from Virginia Tech and the College of William and Mary. Dr. Larson has written on a range of topics with a focus on rural development, natural resource management, food security, carbon markets and trade. With colleagues he has authored or edited six books, and has published in a diverse range of scholarly journals, including the Journal 
of Development Economics, the Journal of Environmental Economics and Management, Annales d'Economie et Statistique, the Journal of Futures Markets and the World Bank Economic Review. He has worked with governments on policy issues in Africa, Asia, Europe, the Caribbean, Latin America and the South Pacific. Dr. Larson was also part of the World Bank team that launched the first climate-finance fund, the Prototype Carbon Fund, in 1999.

Open Access This chapter is licensed under the terms of the Creative Commons Attribution 4.0 International License (http://creativecommons.org/licenses/by/4.0/), which permits use, sharing, adaptation, distribution and reproduction in any medium or format, as long as you give appropriate credit to the original author(s) and the source, provide a link to the Creative Commons license and indicate if changes were made.

The images or other third party material in this chapter are included in the chapter's Creative Commons license, unless indicated otherwise in a credit line to the material. If material is not included in the chapter's Creative Commons license and your intended use is not permitted by statutory regulation or exceeds the permitted use, you will need to obtain permission directly from the copyright holder.

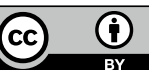

